\title{
Performance of coastal sea-defense infrastructure at EI Jadida (Morocco) against tsunami threat: lessons learned from the Japanese 11 March 2011 tsunami
}

\author{
R. Omira ${ }^{1,2}$, M. A. Baptista ${ }^{2,3}$, F. Leone ${ }^{5}$, L. Matias ${ }^{2}$, S. Mellas ${ }^{4,5}$, B. Zourarah ${ }^{4}$, J. M. Miranda ${ }^{1,2}$, F. Carrilho ${ }^{1}$, and \\ J.-P. Cherel ${ }^{5}$ \\ ${ }^{1}$ Instituto Português do Mar e da Atmosfera (IPMA), Lisbon, Portugal \\ ${ }^{2}$ Instituto Dom Luiz (IDL), Universidade de Lisboa, Lisbon, Portugal \\ ${ }^{3}$ Instituto Superior de Engenharia de Lisboa, Lisbon, Portugal \\ ${ }^{4}$ LGMSS URAC-45, University Chouaïb Doukkali, El Jadida, Morocco \\ ${ }^{5}$ UMR GRED, Université Paul Valéry-Montpellier III, France \\ Correspondence to: R. Omira (omirarachid10@yahoo.fr)
}

Received: 7 November 2012 - Published in Nat. Hazards Earth Syst. Sci. Discuss.: Revised: 22 March 2013 - Accepted: 8 May 2013 - Published: 12 July 2013

\begin{abstract}
This paper seeks to investigate the effectiveness of sea-defense structures in preventing/reducing the tsunami overtopping as well as evaluating the resulting tsunami impact at El Jadida, Morocco. Different tsunami wave conditions are generated by considering various earthquake scenarios of magnitudes ranging from $M_{\mathrm{w}}=8.0$ to $M_{\mathrm{w}}=8.6$. These scenarios represent the main active earthquake faults in the SW Iberia margin and are consistent with two past events that generated tsunamis along the Atlantic coast of Morocco. The behaviour of incident tsunami waves when interacting with coastal infrastructures is analysed on the basis of numerical simulations of near-shore tsunami waves' propagation. Tsunami impact at the affected site is assessed through computing inundation and current velocity using a high-resolution digital terrain model that incorporates bathymetric, topographic and coastal structures data. Results, in terms of near-shore tsunami propagation snapshots, waves' interaction with coastal barriers, and spatial distributions of flow depths and speeds, are presented and discussed in light of what was observed during the 2011 Tohoku-oki tsunami. Predicted results show different levels of impact that different tsunami wave conditions could generate in the region. Existing coastal barriers around the El Jadida harbour succeeded in reflecting relatively small waves generated by some scenarios, but failed in preventing the overtopping caused by waves from others. Considering the scenario highly impact-
\end{abstract}

ing the El Jadida coast, significant inundations are computed at the sandy beach and unprotected areas. The modelled dramatic tsunami impact in the region shows the need for additional tsunami standards not only for sea-defense structures but also for the coastal dwellings and houses to provide potential in-place evacuation.

\section{Introduction}

The Tohoku-oki earthquake of 11 March 2011, with a magnitude of 9.0 (USGS, 2011), triggered a tsunami that caused massive destruction along the northeastern coasts of Japan, $130 \mathrm{~km}$ from the epicentre. Tsunami waves reached the first Japanese mainland area $20 \mathrm{~min}$ after the earthquake (JMA, 2011) and affected about $2000 \mathrm{~km}$ of Japan's Pacific coasts (Mori et al., 2011). A maximum run-up of $39.7 \mathrm{~m}$ was reported from the Sanriku region (Sugawara et al., 2012), and the inundation extended more than $5 \mathrm{~km}$ inland at Sendai Plain (Mori et al., 2011). The catastrophic consequences of this tsunami showed a need to revise the Japanese tsunami mitigation programmes and plans.

Japan is among the countries best prepared to deal with tsunami disaster. The Tohoku-oki tsunami was the first case where sophisticated, well-developed tsunami countermeasures faced such an extreme event. This tsunami revealed 
some limits in the Japanese tsunami mitigation programmes, especially in what concerns the sea-defense structures that were insufficient to protect the coastal population. This fact raised a question on the effectiveness of coastal barriers around the world in preventing/reducing tsunami inundations and, therefore, in protecting the endangered population.

The design and construction of coastal facilities able to stop the tsunami inundation for the at-risk coastal areas remains one of the recommended measures for tsunami hazard mitigation. On the other hand, construction standards of sea-defenses must meet the safety needs of vulnerable zones, which could be derived from impact and damage estimations and predictions.

Japan not only has an effective tsunami warning system (TWS) but also about $40 \%$ of its 22000 miles coastlines (The New York Times, 2011a) is surrounded by different coastal structures designed to protect vulnerable zones from high waves, typhoons or even tsunamis. These coastal defense facilities constructed after the 3 March 1933 Showa Sanriku tsunami include walls, breakwaters, water gates and high-rise river dikes. The protective structures performed well against tsunami inundation during the Tokachi-oki tsunami of 16 May 1968 (Edward et al., 2006). However, the $M_{\mathrm{w}}=9.0$ event of 11 March 2011 far exceeded the maximum credible earthquake anticipated, generating a tsunami that exceeded the Japanese tsunami standards. During this event, the overtopping of Japanese sea-defense facilities occurred, and sea-walls provided limited protection to the endangered population. Even though the defensive walls contributed to the reduction of the tsunami catastrophic potential by slowing down the waves' propagation and reducing their energy, catastrophic human and economic losses were caused. This fact shows that there is always a possibility to exceed the tsunami design standards even for an unprecedented event of extreme rarity.

In the North East Atlantic region, the countries most exposed to tsunamis are Morocco, Portugal, and Spain (Baptista and Miranda, 2009; Kaabouben et al., 2009; Ruiz et al., 2005). In these countries, coastal and sea-defense structures are not designed to withstand the tsunami impact and serve only as breakwaters that protect marinas and harbour facilities from ocean wind waves.

In the present study, we investigate the performance of existing coastal barriers and infrastructures against the tsunami overtopping as well as evaluating the resulting tsunami impact at El Jadida (Morocco) site. The city of El Jadida is one of the Moroccan Atlantic zones that were ravaged by the 1 November 1755 Lisbon tsunami, as described in various tsunami historical works (Blanc, 2009; Kaabouben et al., 2009). The town has known, during the last decades, a significant growth of coastal urbanisation that resulted in the construction of various coastal facilities, dwelling houses and tourism projects along its coast. However, no tsunami protection measures have been put in place in order to mitigate the possible tsunami impact. Therefore, the occurrence of a 1755-like tsunami event could cause massive human and material losses in the region.

The paper considers submarine earthquakes as the main source of tsunami generation in the Gulf of Cadiz, in spite of some landslides reported in historical catalogues (Baptista and Miranda, 2009), to trigger tsunamis of local effects in the region. We consider five tsunamigenic scenarios, all of seismic origin, in this study. These scenarios, of magnitudes raging from 8.0 to 8.6 , represent the main active earthquake faults in the SW Iberia margin that are able to trigger large tsunamis in the region. The lower magnitude $\left(M_{\mathrm{w}}=8.0\right)$ is compatible with the 28 February 1969 event, while the higher magnitudes $\left(M_{\mathrm{W}}=8.2-8.6\right)$ are considered to represent the 1 November 1755 event. We perform a numerical modelling of tsunami propagation for all considered scenarios and inundation for the scenario causing the worst impact in the studied area.

Tsunami inundation and overland waves' propagation are critically dependent on the quality of both digital terrain and numerical tsunami propagation models. The digital terrain model must include a complete description of the bathymetry, topographic and coastal infrastructure (Leone et al., 2010), while the numerical model must be validated using realistic cases. The generation of the high-resolution digital terrain model was supported by cartographic data and field surveys in order to better describe both natural and man-made coastal features in the region. On the other hand, the reliability of the numerical model, employed to simulate both tsunami propagation and inundation, was tested within the framework of the TRANSFER EU project (TRANSFER, 2009) against the benchmark tests proposed by Synolakis et al. (2007). Benchmarking results show good performances of the numerical code for various tests. Also, this code has been successfully used to simulate various historical tsunamis, such as the 1755 Lisbon event (Baptista et al., 2011a), and recent events, such as the 2004 Sumatra tsunami (Wijetunge, 2009), showing good agreements with observations.

Simulated near-shore waves show differences in characteristics and behaviour between waves generated by the various tsunami scenarios considered in this study. The analysis of the interaction of these computed waves with coastal structures and the possibility of overtopping allows testing the effectiveness of coastal protective facilities in preventing/reducing tsunami inundation. Existing coastal barriers at El Jadida succeeded in reflecting waves of relatively small amplitudes generated by some of the considered scenarios, but failed in preventing the overtopping from tsunami scenarios causing high near-shore waves. Unprotected coastal areas, such as the beach of the city of El Jadida, suffered significant simulated flooding compared to other protected zones.

We present the results in terms of near-shore tsunami waves' behaviour, their interaction with coastal structures and the resulting inundations and current velocities. Finally, we discuss those results in light of observations from the 

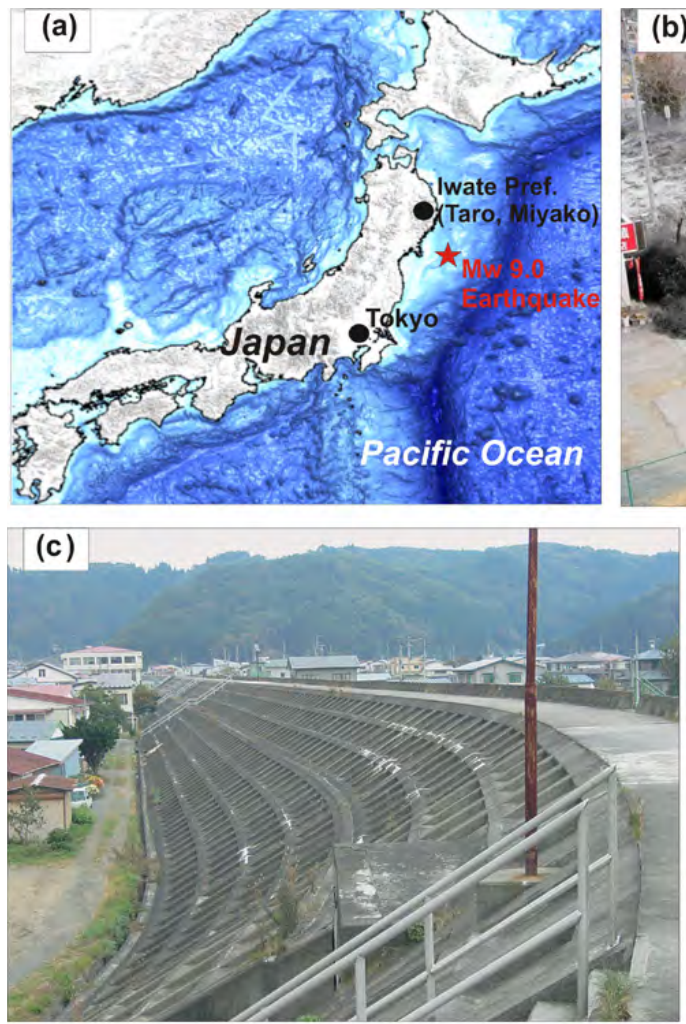

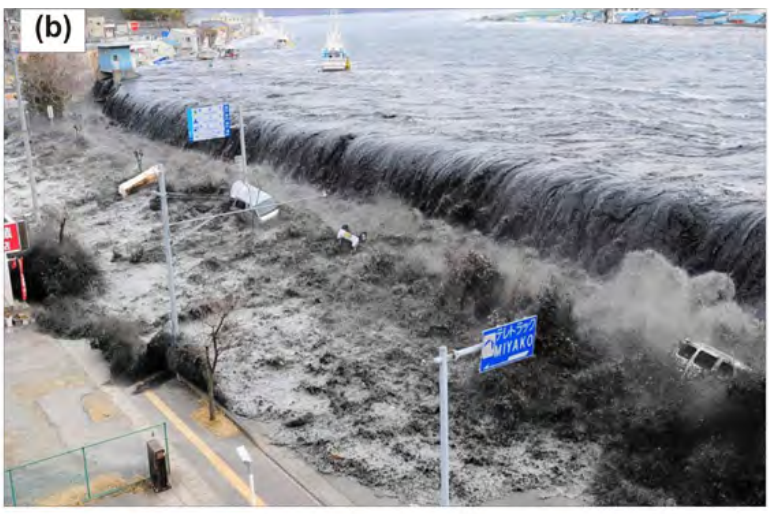

(d)

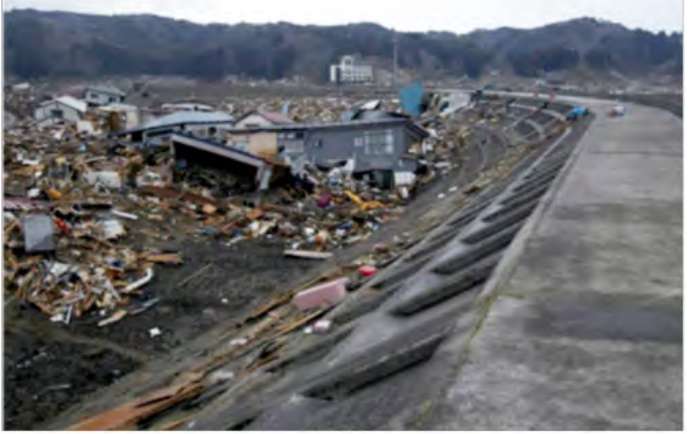

Fig. 1. The Tohoku, 11 March 2011, Tsunami event of Japan: (a) epicentre location of the earthquake from USGS (2011); (b) the 11 March tsunami overtopping the $40 \mathrm{ft}$ sea-wall at Miyako city (source: Mainichi Shimbun/Reuters in The New York Times, 2011a); (c) sea-wall of $10 \mathrm{~m}$ height in Taro N-E Japan (adapted from Edward et al., 2006); (d) the devastating impact in the city of Taro after the 11 March 2011 Japanese tsunami that overtopped the sea-wall (source: Ko Sasaki for The New York Times, 2011b).

11 March 2011 Japanese tsunami. Here, we use these observations from the Japanese event not to make a direct comparison with the El Jadida case but to serve as lessons for future tsunami preparedness and mitigation programmes in the studied zone.

\section{Lessons learned from the Japanese tsunami}

The tsunami that struck Japan on 11 March 2011 triggered by a $M_{\mathrm{w}}=9.0$ earthquake (see Fig. 1a for location), highlighted the fact that there is always a possibility of exceedance of tsunami design standards. The unprecedented $M_{\mathrm{w}}=9.0$ event far exceeded the anticipated maximum credible earthquake and the resulting tsunami far exceeded predicted runup and inundation distances. The devastating tsunami generated a maximum run-up of $39.7 \mathrm{~m}$ at Miyako and propagated more than $5 \mathrm{~km}$ inland at Sendai Plain (Mori et al., 2011). Against this huge tsunami, the Japanese defensive facilities provided limited protection to the endangered coastal population. In some cases, the coastal barriers were severely damaged or failed structurally due to massive scour of the onshore toe or to the return flow (EERI, 2011), while sea-walls that survived the waves impact helped limit tsunami damage even though they were overtopped.
The massive impact of the 2011 Tohoku-oki tsunami was mainly observed along the northeastern Pacific coasts of Japan. The city of Miyako has known a large inundation after the overtopping of the $40 \mathrm{ft}(\sim 12 \mathrm{~m})$ sea-wall (Fig. 1b). In this town, the ASCE-EERI team (American Society of Civil Engineering - Subcommittee on Tsunami Loads \& Effects) examined areas inside and outside the sea-wall during a posttsunami survey and found a remarkable difference showing more than $90 \%$ of unprotected area destroyed, while only localised damages were observed behind the sea-wall (EERI, 2011). Moreover, the extent of damage was minimal on the lee of the $15.5 \mathrm{~m}$ high sea-wall that was overtopped by a $18.1 \mathrm{~m}$ wave at Fudai (EERI, 2011; Suppasri et al., 2012). These facts clearly indicate that sea-walls of Japan, even though overtopped, helped mitigating tsunami effects. At the Taro fishing town, Japan's northeastern coast, the tsunami impact was devastating. Waves washed over a sea-wall that stretches for $2.4 \mathrm{~km}$ and rises as high as $10 \mathrm{~m}$ (Fig. 1c), advancing inland, carrying with them wooden dwellings and only a few RC buildings withstood the impact (Fig. 1d). Several survivors of the 11 March disaster at Taro town have testified that the presence of sea-walls may have provided a false sense of safety to the endangered coastal population 
(The New York Times, 2011b). Some of Taro's population stood and waited for the arrival of the tsunami waves and the overtopping of the barriers before running for their lives to higher ground.

On the other hand, tsunami warning was successfully disseminated by the Japan Meteorological Agency (JMA) a few minutes $(\sim 3 \mathrm{~min})$ after the earthquake occurrence (JMA, 2011). Nevertheless, this initial issued tsunami alert was based on an under-estimated magnitude of 7.9, leading to the underestimation of the wave amplitudes' prediction along Japan's coasts. During the event, based on tsunami observations from offshore and tide gauges sensors, JMA raised tsunami warning grades and widened warning areas seven times (Ozaki, 2011), whereas the first upgrade was $28 \mathrm{~min}$ after the earthquake. However, due to the close location of the earthquake epicentre (Fig. 1a), $\sim 130 \mathrm{~km}$ off the northeast coast and, therefore, the short arrival time of the subsequent tsunami waves to the nearest coasts, the evacuation process was difficult to apply in some areas.

In summary, we can conclude that without the tsunami countermeasures, the effects of the 11 March 2011 tsunami would have likely been even worse. The presence of a sophisticated TWS saved many lives by providing a tsunami warning a few minutes after the earthquake occurrence. Also, tsunami education and preparedness programmes led the Japanese population to react appropriately to the disseminated alert. In addition, coastal sea-defenses, even though overtopped, helped slow down the tsunami waves and reduced the extent of impact.

\section{Study area and characteristics of coastal defense infrastructure}

The studied area of about $4.5 \mathrm{~km} \times 1.5 \mathrm{~km}$ corresponds to El Jadida site, a port city on the Atlantic coast of Morocco, characterised by a high coastal occupation and various touristic activities (Fig. 2). Known as Mazagão under the Portuguese, they held it from 1502 to 1769 and constructed the Old Portuguese Medina and its $\sim 11 \mathrm{~m}$ height wall. From the early 19th century, the city has known a great amount of development in terms of coastal structures and occupation that has resulted in the construction of the harbour, various tourist projects and infrastructures along the coast. The city's population is estimated as more than 250000 inhabitants. This population grows significantly during high season, corresponding to the summer period when the city experiences its important touristic activity. Moreover, the Atlantic coast of Morocco is also characterised by its important tidal variations. The tidal amplitude along this coast is up to $4 \mathrm{~m}$ (Russell, 2010). At near-shore El Jadida the high-tide amplitude reaches $\sim 2.9 \mathrm{~m}$ (MET, 2011).

From a tsunami risk point of view, the city of El Jadida was one of the Moroccan Atlantic sites ravaged by the 1 November 1755 Lisbon tsunami, as described in various

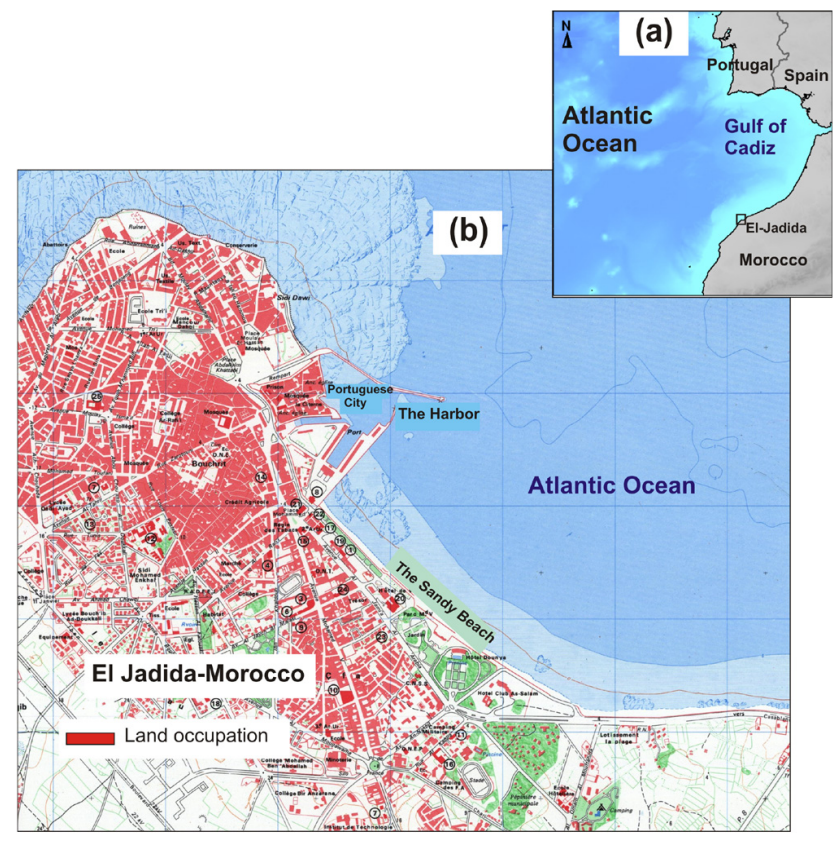

Fig. 2. Study area: (a) regional overview of the Gulf of Cadiz area and the location of El Jadida site in the Atlantic coast of Morocco; (b) studied site including the harbour and the beach of the city as well as the land occupation (1: 10000 urban plan of El Jadida; Source: Direction of conservation and land surveying, RabatMorocco).

tsunami historical works (Blanc, 2009; Kaabouben et al., 2009). Moreover, the study by Omira et al. (2009) indicates that this site is the first on the Moroccan Atlantic coast to be reached by tsunami waves triggered by regional earthquakes generated in SW Iberia. This fact suggests that El Jadida should be an official "forecast point" in the future implementation of a tsunami early warning system in NE Atlantic. Considering the studied site as a "forecast point" will serve to warn other coastal areas where the tsunami takes more time to reach.

The field survey conducted along the El Jadida coastal area focused on the identification and characterisation of existing sea-defense infrastructures (Fig. 3). It revealed the presence of some breakwaters and protective structures that consist of (i) a rubble mound breakwater armoured by concrete tetrapods (Figs. 3b.1 and b.2), (ii) a mortared stone groin (Fig. 3b.3), (iii) concrete vestigial sea-walls of $\sim 2-3 \mathrm{~m}$ (Fig. 3c.2) and of $\sim 1 \mathrm{~m}$ (Fig. 3c.3) in height that separate the sandy beach from the rest of the city, and (iv) an $11 \mathrm{~m}$ high wall surrounding the Old Medina (Fig. 3c.1). The breakwaters, which are offshore sea-defense structures, are usually designed to shelter the harbour basin and the entrance against the waves. On the other hand, the sea-wall, which is an onshore barrier, is constructed in order to reduce the erosion risk at the coastal zone and may also be useful to stop waves. 
(a)

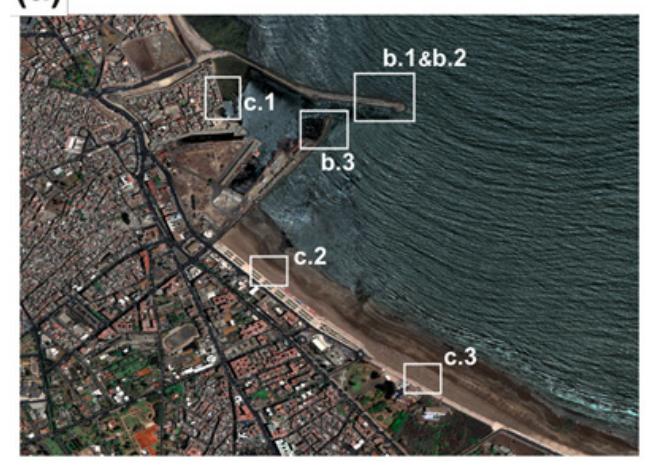

\section{(b)}
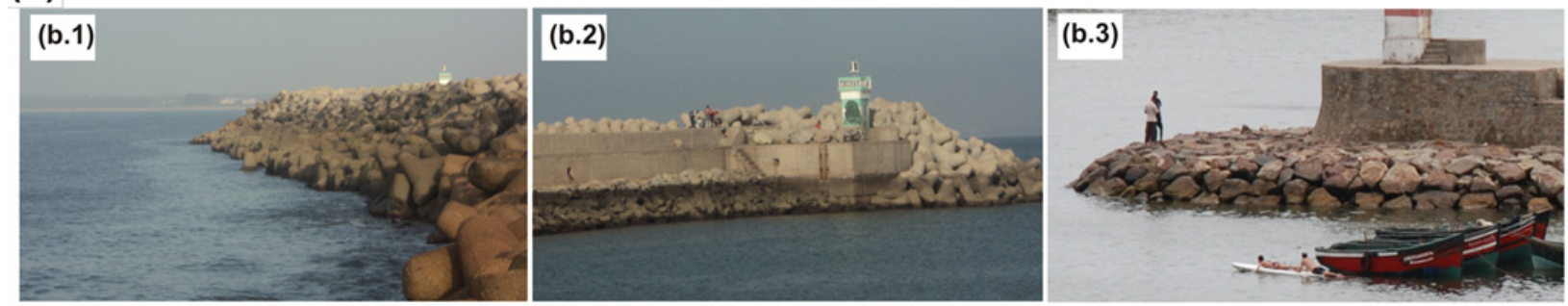

(c)
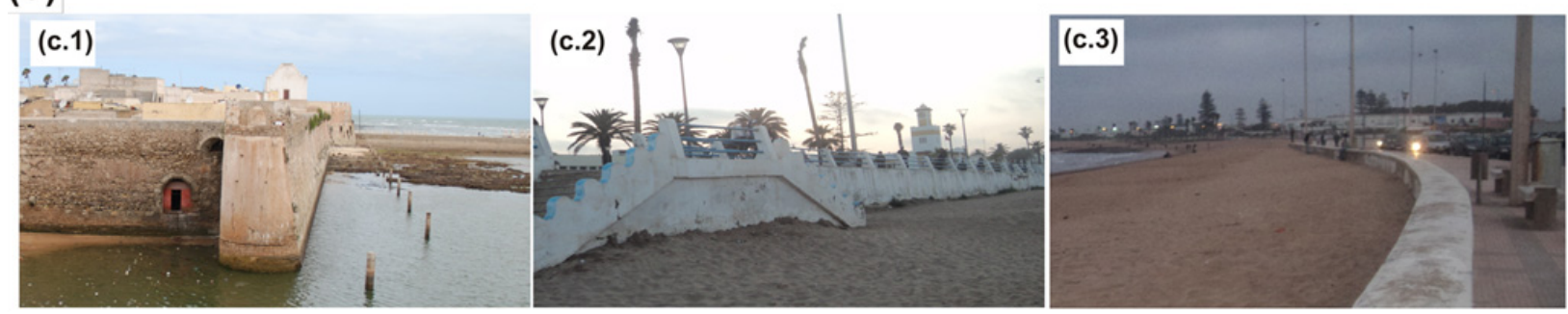

Fig. 3. Coastal sea-defense identification and characteristics in the studied site: (a) location of the visited areas; (b) harbour breakwaters; (c) sea-walls along the El Jadida coast.

In summary, preliminary observations reveal the absence of any specific tsunami-resistant and/or evacuation design for these structures. In view of this, we investigated the effectiveness of the existing infrastructures considering five earthquake/tsunami scenarios that generate different wave conditions near-shore.

\section{Tsunamigenic scenarios}

We perform tsunami impact modelling for the El Jadida site using five tsunami scenarios produced by different submarine earthquakes of magnitudes ranging from 8.0 to 8.6. Considering the scenarios of these magnitude ranges, we cover the events that occurred on 28 February 1969 (Baptista et al., 1992; Gjevik et al., 1997) and on 1 November 1755 (Baptista et al., 1998). With this approach, we produce different wave conditions near-shore, and we examine the effectiveness of the existing defense structures in preventing/reducing inundation.
The 28 February 1969 earthquake $\left(M_{\mathrm{S}}=7.9\right)$ occurred in the Horseshoe Abyssal Plain zone (HAPZ) and triggered a small tsunami in the Gulf of Cadiz region. The relatively deep fault rupture of this earthquake, $\sim 23 \mathrm{~km}$ from the sea floor (Fukao, 1973), was the main factor that controlled the amplitudes of the associated tsunami waves. Hence, tidegauge stations in Portugal, Spain, and Morocco recorded only a small tsunami with a maximum of $0.9 \mathrm{~m}$ downward at Casablanca, Morocco (Omira et al., 2010). Here, we consider a shallower rupture mechanism for a $M_{\mathrm{w}}=8.0$ scenario that we assume as a 1969-like event (see Table 1), which allows for the generation of more significant tsunami waves along the Atlantic coasts of Morocco. On the other hand, scenarios of larger magnitudes $\left(\geq M_{\mathrm{w}}=8.2\right)$ are considered compatible with the 1755 event $\left(M_{\mathrm{w}}=8.5 \pm 0.3\right.$ recently reevaluated from macro-seismic field survey; Martinez-Solares and Lopez-Arroyo, 2004) known to trigger a large tsunami that impacted the coast of El Jadida. The effects of the 1755 tsunami along Moroccan coasts are extensively described in various works (El-Mrabet, 1991; Kaabouben et 
Table 1. Fault parameters of considered tsunamigenic scenarios compatible with both 1969 and 1755 events. Scenarios: HS (Horseshoe), MP (Marques de Pombal), GB (Gorring Bank), CW (Cadiz Wedge); $L$ : the fault length in km; $W$ : the fault width in km; $D$ : the depth from the sea bottom to the top of the fault in $\mathrm{km} ; \mu$ : the shear modulus; and $M_{\mathrm{W}}$ : the moment magnitude.

\begin{tabular}{|c|c|c|c|c|c|c|c|c|c|c|c|c|}
\hline \multicolumn{2}{|c|}{ Scenario } & \multirow[t]{2}{*}{$\begin{array}{l}L \\
(\mathrm{~km})\end{array}$} & \multirow[t]{2}{*}{$\begin{array}{l}W \\
(\mathrm{~km})\end{array}$} & \multicolumn{2}{|c|}{$\begin{array}{l}\text { Epicentre } \\
\text { coordinates }\end{array}$} & \multirow[t]{2}{*}{$\begin{array}{l}D \\
(\mathrm{~km})\end{array}$} & \multirow[t]{2}{*}{$\begin{array}{l}\text { Slip } \\
(\mathrm{m})\end{array}$} & \multirow[t]{2}{*}{$\begin{array}{l}\text { Strike } \\
\left({ }^{\circ}\right)\end{array}$} & \multirow[t]{2}{*}{$\begin{array}{l}\text { Dip } \\
\left(^{\circ}\right)\end{array}$} & \multirow[t]{2}{*}{$\begin{array}{l}\text { Rake } \\
\left({ }^{\circ}\right)\end{array}$} & \multirow[t]{2}{*}{$\begin{array}{l}\mu \\
(\mathrm{Pa})\end{array}$} & \multirow[t]{2}{*}{$M_{\mathrm{W}}$} \\
\hline & & & & Lon & Lat & & & & & & & \\
\hline 1969-like & HS & 105 & 60 & -9.9 & 35.8 & 4.0 & 4.0 & 42 & 35 & 90 & $4.5 \times 10^{10}$ & 8.0 \\
\hline \multirow[t]{4}{*}{ 1755-like } & HS & 165 & 70 & -9.9 & 35.6 & 4.0 & 12.0 & 42 & 35 & 90 & $4.5 \times 10^{10}$ & 8.5 \\
\hline & MP & 120 & 70 & -9.8 & 36.6 & 4.0 & 8.0 & 20 & 35 & 90 & $4.5 \times 10^{10}$ & 8.2 \\
\hline & GB & 200 & 80 & -11.3 & 36.7 & 4.0 & 10.0 & 53 & 35 & 90 & $4.5 \times 10^{10}$ & 8.5 \\
\hline & $\mathrm{CW}$ & 168 & 200 & -8.1 & 35.1 & 4.0 & 10.0 & 349 & 5 & 90 & $3.0 \times 10^{10}$ & 8.6 \\
\hline
\end{tabular}

al., 2009; Blanc, 2009). This event was transoceanic and tsunami-generated waves impacted the eastern Lesser Antilles, the Newfoundland and Canada north, and the coasts of Brazil south (Kozak et al., 2005; Ruffman, 2006). Barkan et al. (2009) investigated the far-field tsunami modelling for the 1755 Lisbon event and show significant tsunami waves reaching the US eastern and Caribbean coasts.

To simulate the ocean bottom deformation due to these earthquakes, we select the main active earthquake faults located offshore of SW Iberia; namely, the Cadiz Wedge (CW) fault (Gutscher et al., 2002), the Horseshoe (HS) fault (Gràcia et al., 2006), the Marques de Pombal (MP) fault (Zitellini et al., 1999), and the Gorringe Bank (GB) fault (Johnston, 1996) (see Fig. 4a). Compared to tsunamigenic faults that have been identified by geological studies in the SW Iberia margin the dimensions of the scenarios that are considered in this study, except the 1969-like scenario, have been extended in order to be in agreement with the worst case magnitude. The scaling relationship of Scholz (1982) that is based on fault lengths and length/width relation has been used to obtain the slip magnitude of each scenario. The sources HS, MP, and GB are considered thrust and thus a fixed dip of $35^{\circ}$ is adopted in agreement with Omira et al. (2009). For the $\mathrm{CW}$ a minimum dip of $5^{\circ}$ is used as the source corresponds to the basis of an accretionary wedge (Gutscher et al., 2006). Regarding the shear modulus $(\mu)$ that characterises the rigidity of the earthquake rupture area, a value of $4.5 \times 10^{10} \mathrm{~Pa}$ is chosen for HS, MP and GB, as a higher value of $6.5 \times 10^{10} \mathrm{~Pa}$ would be more appropriate for large width faults that rupture also the upper mantle (Matias et al., 2013). A lower $\mu$ value of $3 \times 10^{10} \mathrm{~Pa}$ is adopted for the $\mathrm{CW}$ that occurs in a subduction slab roll-back source area according to Gutscher et al. (2002). It is important to note that a change of $\mu$ from $4.5 \times 10^{10} \mathrm{~Pa}$ to $6.5 \times 10^{10} \mathrm{~Pa}$, for example, would imply an increase of 0.1 in $M_{\mathrm{w}}$ without any change in the tsunami amplitudes simulated. Fault parameters for the studied scenarios are illustrated in Table 1. In Fig. 4a the scenarios are plotted.

\section{Tsunami numerical modelling}

Numerical modelling of near-shore tsunami behaviour, impact, inundation, and current velocity is investigated in order to test the effectiveness of coastal infrastructures against tsunami incident waves. To simulate the tsunami propagation, we use a nonlinear shallow water code and a high resolution digital terrain model that incorporates bathymetric, topographic, and coastal man-made infrastructures data.

\subsection{Digital terrain model}

A set of bathymetric/topographic data grids is generated to cover the areas from the Gulf of Cadiz to the studied site. The grid layers have spatial increasing resolutions with grid sizes of $320 \mathrm{~m}, 80 \mathrm{~m}, 20 \mathrm{~m}$, and $5 \mathrm{~m}$. They are nested for consecutive calculations of tsunami generation, propagation and inland inundation.

Bathymetric data for the parent grid, $320 \mathrm{~m}$ resolution, which extends from $33^{\circ} \mathrm{N}$ to $40^{\circ} \mathrm{N}$ and from $5^{\circ} \mathrm{W}$ to $13^{\circ} \mathrm{W}$ including the tsunamigenic sources region (Fig. 4a), are compiled using multisource height/depth data from the General Bathymetric Chart of the Oceans one minute data (GEBCO, 2011), together with the SW Iberian margin bathymetry compilation (Zitellini et al., 2009). This compilation was completed with digitised bathymetric charts and digital cartographic data in order to assure a good description of bathymetric and topographic features in the region. Two intermediate grids of resolutions $80 \mathrm{~m}$ and $20 \mathrm{~m}$ are incorporated in the nested grids system for numerical stability requirements. The $80 \mathrm{~m}$ sub-grid covers the Atlantic coastal segment of Morocco from Casablanca to the north to Safi to the south, while the $20 \mathrm{~m}$ grid focuses on El Jadida and the surrounding regions. Both intermediate grids are obtained by interpolating the parent grid to 80 and $20 \mathrm{~m}$ resolutions. For the site of interest a $5 \mathrm{~m}$-resolution grid is generated.

The near-shore grid layer of $5 \mathrm{~m}$ resolution (Fig. 4b), which focuses on the studied site, incorporates highresolution bathymetric, topographic and coastal man-made infrastructures data. The generation of this grid was 
(a)

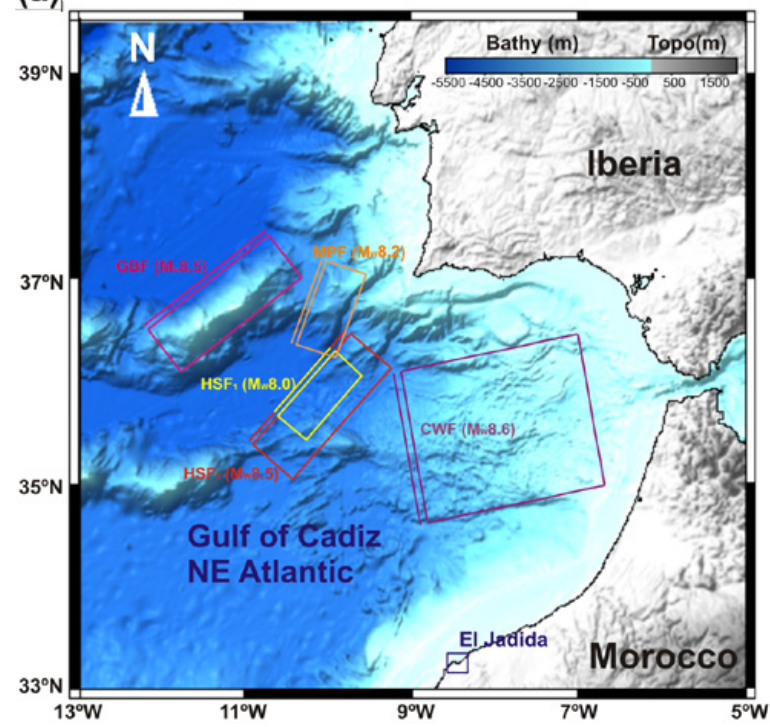

(b)

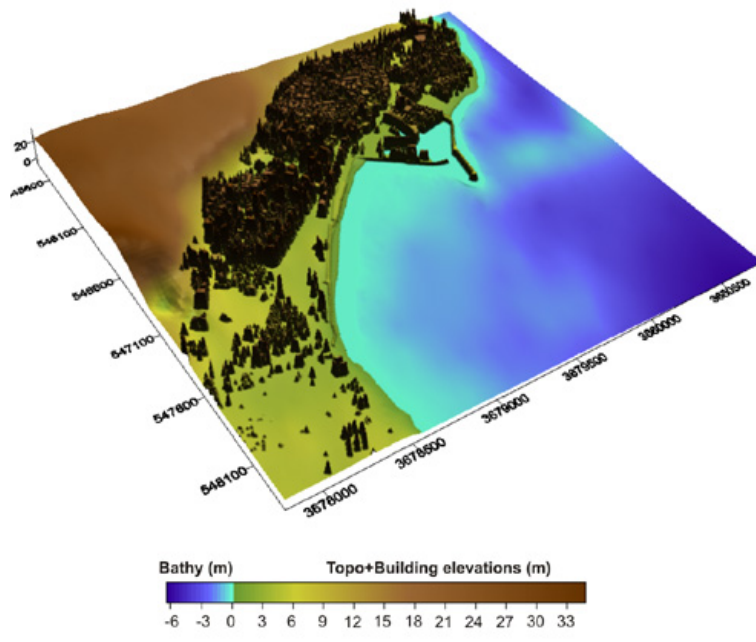

Fig. 4. Tsunamigenic scenarios and digital elevation models: (a) regional bathy/topo of the Gulf of Cadiz region and the considered tsunami scenarios, GBF: Gorringe Bank fault, MPF: Marques de Pombal fault, HSF: Horseshoe fault, CWF: Cadiz Wedge fault; (b) $5 \mathrm{~m}$ resolution digital elevation model incorporating bathymetric, topographic and coastal buildings and sea-defense infrastructures data for the El Jadida site.

supported by both field surveys and cartographic data. Topographic data were obtained from SDAU - El Jadida (2004) that used the GPS to collect offshore elevations of the study area in the form of points with precise coordinates. This dataset is then enriched with digitised points from a $1: 50000$ topographic map along the contours lines of 5$35 \mathrm{~m}$. The bathymetric data were obtained from the digitalisation of high-resolution bathymetric charts, $1: 50000$ scale, of El Jadida site. The zero height contour line of the study site was digitised from a satellite image and then used for landsea transition. Coastal infrastructures information including geometries and elevations of both coastal buildings and protective structures were obtained from SDAU - El Jadida and field surveys. These data were in the form of vectors that are converted to a matrix in order to be integrated with the constructed bathymetric/topographic layer using the GIS environment tools. The result of these processes was the generation of a 5 m-resolution grid layer (Fig. 4b), allowing a better representation of bathymetric, topographic and coastal structures in order to conduct more realistic modelling of tsunami impact in the region of El Jadida, Morocco. The elaborated $5 \mathrm{~m}$-resolution digital terrain model represents properly the coastal protective structures identified in the Sect. 3.

\subsection{Numerical model}

The initial sea surface perturbation is generated for the submarine earthquake scenarios described in Sect. 4. The earthquake rupture is supposed instantaneous and the sea-bed displacement is computed using the half-space elastic theory (Okada, 1985). As the slip distribution affects the near- shore waveform (Geist, 2005; MacInnes et al., 2010) and, therefore, the near-field tsunami run-up, we adopt a discretised dip-directed slip distribution along the fault plane, following the smooth closure condition proposed by Geist and Dmowska (1999). The vertical sea bottom displacement is then transferred to the free ocean surface with the assumption that both deformations of sea bottom and ocean surface are equal (Kajiura, 1970). The basic fault parameters for earthquake scenarios used in tsunami modelling are summarised in Table 1.

We adopt the linear and nonlinear approximations of shallow water equations (SWEs) to simulate the tsunami propagation. In the deep ocean the linear approximation of SWEs, which consists of neglecting the nonlinear convective inertia force, is valid since the waves travel with amplitudes much smaller than the water depths. Hence, we use the linear formulation to simulate the tsunami propagation for the deep ocean domain. When tsunami-generated waves approach coastal regions and propagate into shallow water, the nonlinear convective inertia force and bottom friction effects become increasingly important. In such a case, the linear approximation is no longer valid. Therefore, for an adequate simulation of near-shore tsunami propagation and overland inundation at the site of interest, we employ the nonlinear SWEs including bottom friction. We use the adapted version COMCOT-Lx (Omira et al., 2009; Omira et al., 2010; Baptista et al., 2011a) of COMCOT code (Liu et al., 1998) to solve these equations numerically. This code employs a dynamically coupled system of nested grids and solves SWEs using an explicit staggered leap-frog finite differences 
numerical scheme for linear terms and an upwind scheme for the nonlinear terms (Wang, 2009).

Using a nested grid system, COMCOT-lx is capable of simultaneous calculation of tsunami propagation in open ocean and inundation in targeted coastal zones. In the nested grid system, the inner (finer grid) region adopts a smaller grid size and time step and is nested inside an outer (larger grid) region. In our case, a system of four nested grids is used: the $5 \mathrm{~m}$ resolution grid is nested inside the $20 \mathrm{~m}$ resolution grid, the $20 \mathrm{~m}$ resolution grid is nested inside the $80 \mathrm{~m}$ resolution grid, and the $80 \mathrm{~m}$ resolution grid is nested inside the $320 \mathrm{~m}$ resolution grid. At the beginning of each time step, along the interface of two different regions, the volume flux, which is the product of water depth and depth-averaged velocity, is interpolated from the outer region into the inner region. The water surface elevations and the volume fluxes in the inner region are calculated and the resulting free-surface elevations are averaged to update those values in the larger grid, which overlaps the inner region.

In all considered computation domains, the code employs radiation (or absorbing) boundary conditions, which have the property that the wave motion passes from one domain to another through the boundaries with small reflections (Broeze and Van Daalen, 1992). The moving boundary treatment (Liu et al., 1995), based upon "wet" and "dry" cells, is adopted to properly track shoreline movements in order to compute the overland flooding. During the inundation process, we suppose that both natural and man-made coastal infrastructures play the role of resistant obstacles, and possible tsunami damages to these structures are not estimated by numerical simulations. The interaction tide-tsunami is not considered in numerical simulations performed in this study.

\section{Results}

\subsection{Near-shore propagation and interaction with coastal infrastructures}

To investigate the behaviour of tsunami waves when approaching the shoreline and how they interact with coastal infrastructures, we analyse detailed tsunami propagation close to the El Jadida harbour. Figures 5, 6, 7, 8, and 9 present computed results for all considered scenarios, including regional tsunami energy propagation patterns, and both nearshore propagations and maximum wave heights. We consider, in our simulations, an entire tsunami propagation time of $2 \mathrm{~h} 30 \mathrm{~min}$ for all scenarios, taking into account the necessary time for both tsunami arrival and possible overland propagation.

\subsubsection{The Horseshoe (HS) scenario $M_{\mathrm{w}}=8.0$}

The examination of simulations results indicates that the tsunami energy from the $M_{\mathrm{w}}=8.0 \mathrm{HS}$ scenario (1969-like event) is mostly steered towards the NW coasts of Morocco

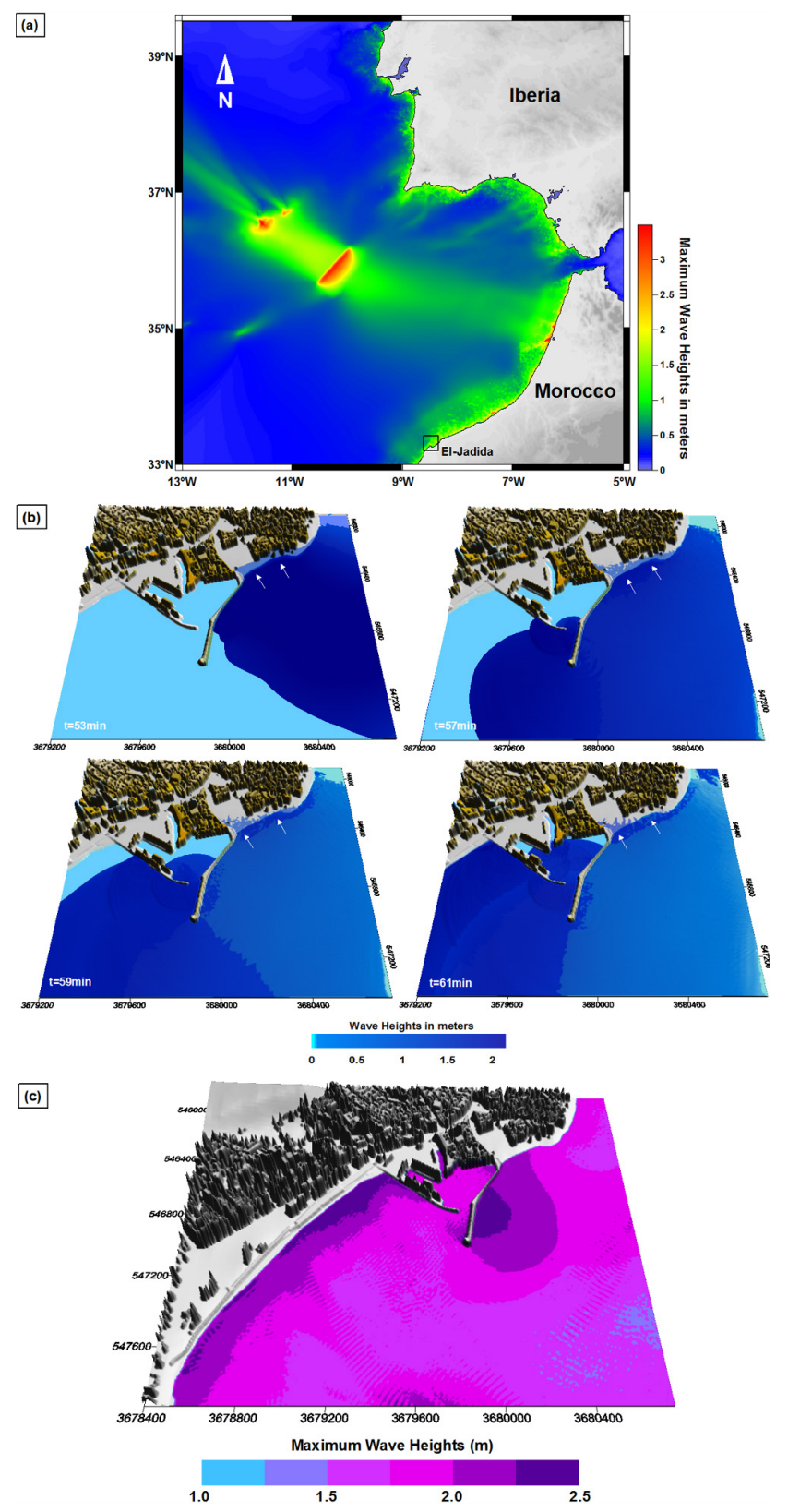

Fig. 5. Tsunami waves' propagation and near-shore behaviour for the $M_{\mathrm{W}}=8.0$ HS scenario: (a) regional tsunami energy patterns; (b) snapshots of near-shore tsunami propagation at El Jadida site; the white arrows indicate the overtopping locations; (c) maximum wave heights distribution near coasts and the harbour of the studied area.

(Fig. 5a). This scenario generated tsunami waves that are mainly stopped by the coastal barriers surrounding the harbour (Fig. 5b). As the incident waves approach the harbour, they encounter the breakwaters leading to reflect the waves and hence, to disperse the tsunami energy (Fig. 5b). The computed maximum wave heights from a 1969-like tsunami event range from 1 to $2.5 \mathrm{~m}$ near-shore El Jadida harbour 
(Fig. 5c). These waves, relatively small in terms of amplitude, do not succeed in overtopping the breakwaters, which shelter the harbour basin against the entrance of tsunami waves with high energy. On the other hand, results show that generated waves advance overland in some unprotected areas (indicated by white arrows in Fig. 5c).

\subsubsection{The Horseshoe (HS) scenario $M_{\mathrm{w}}=8.5$}

As expected, tsunami waves resulting from the $M_{\mathrm{W}}=8.5$ scenario (1755-like event, Gràcia et al., 2006) cause greater impact than those generated by the 1969-like event. The tested $M_{\mathrm{w}}=8.5$ earthquake scenario located at the HAPZ triggered a tsunami that overtops the existing breakwaters and the beach sea-walls. Only the $11 \mathrm{~m}$ height wall prevents the entrance of tsunami waves to the Old Medina. The white arrows in Fig. 6a indicate the overtopping locations. Close to the harbour, in spite of the fact that the breakwaters play a role as an obstacle for incident waves and reflect a part of them (Fig. 6b), the waves can still overtop the barriers, entering the harbour basin and propagating overland, leading to significant inundation. Predicted maximum wave amplitudes range from $4 \mathrm{~m}$ to about $9 \mathrm{~m}$ (Fig. 6c) near-shore El Jadida. These values of wave height justify the overtopping of breakwaters and other existing coastal barriers as shown in the computed waves' propagation snapshots (Fig. 6b).

\subsubsection{The Marques de Pombal (MP) scenario $M_{\mathrm{w}}=8.2$}

The $M_{\mathrm{w}}=8.2 \mathrm{MP}$ scenario, located $100 \mathrm{~km}$ off SW Iberia, is based on a large active tectonic structure that is considered one of the candidates source for the 1755 event (Zitellini et al., 1999). Numerical simulations show that the $M_{\mathrm{w}}=8.2$ MP scenario triggered a large tsunami in the Gulf of Cadiz region (Fig. 7a). The shallower water depth in the area off SW Iberia acts as a guide for tsunami energy from the northern area of the MP fault to the southern coasts of Portugal leading to a lower concentration of tsunami impact along the Atlantic coasts of Morocco (Fig. 7a). The analysis of nearshore tsunami waves, generated by this scenario, indicates that waves with relatively small amplitudes $(\sim 2 \mathrm{~m})$ reach the harbour of El Jadida in spite of the moderate event's magnitude (Fig. 7b). In view of this, El Jadida protective structures reflect the tsunami waves with no significant overtopping (Fig. 7c). The wave amplitudes are as high as $3 \mathrm{~m}$ in some locations surrounding the harbour, with some significant inundation threats in unprotected areas (white arrows in Fig. 7b).

\subsubsection{The Gorringe Bank (GB) scenario $M_{\mathrm{w}}=8.5$}

The $M_{\mathrm{w}}=8.5 \mathrm{~GB}$ scenario, for which the Gorringe Bank is in the hanging wall, is considered as a candidate source for the 1755 Lisbon event (Johnston, 1996). Numerical simulation shows a tsunami energy steering towards the north as the Gorringe Bank's bathymetric feature prevents an efficient

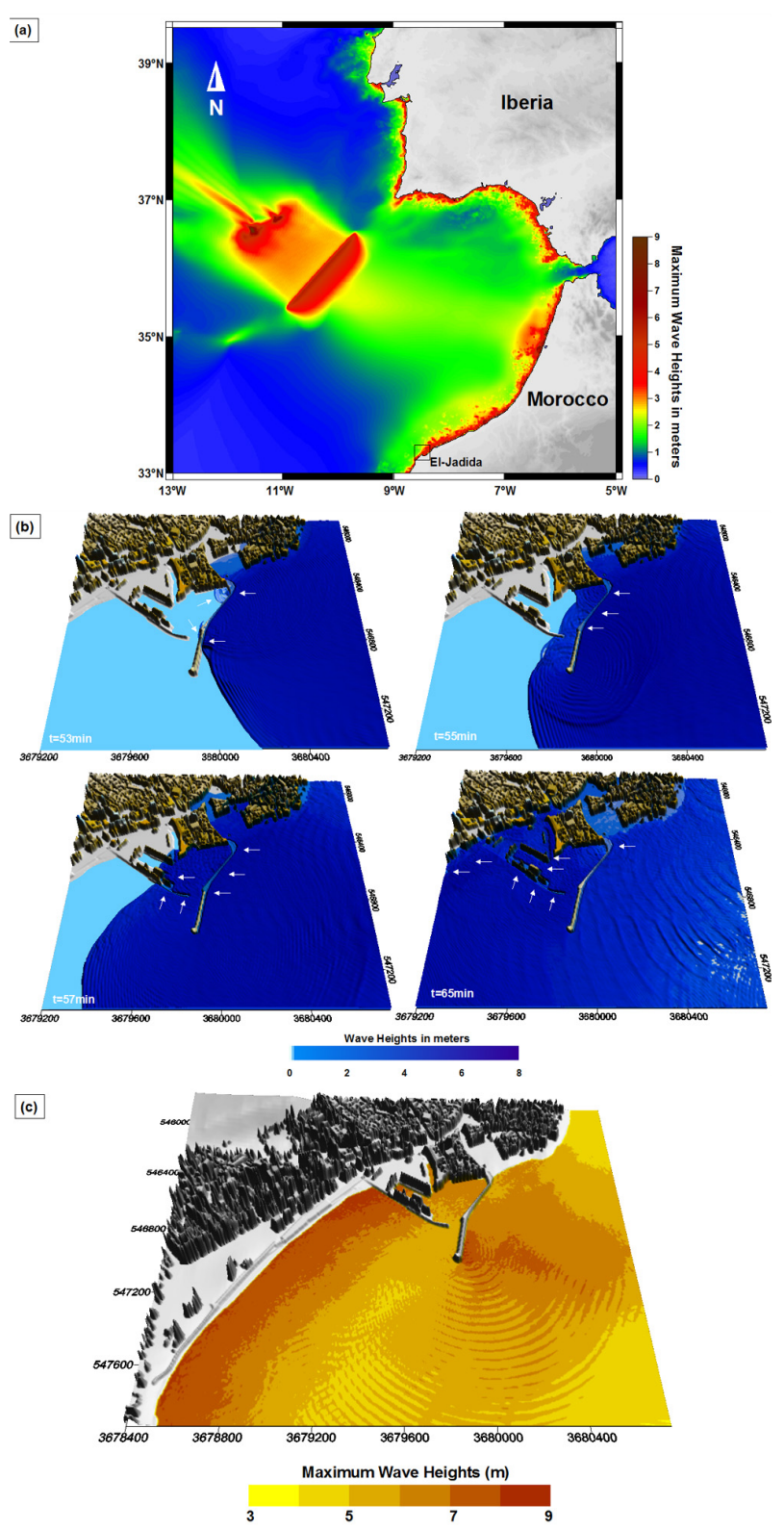

Fig. 6. Tsunami waves' propagation and near-shore behaviour for the $M_{\mathrm{W}}=8.5$ HS scenario: (a) regional tsunami energy patterns; (b) snapshots of near-shore tsunami propagation at El Jadida site; the white arrows indicate the overtopping locations; (c) maximum wave heights distribution near coasts and the harbour of the studied area.

propagation towards the Gulf of Cadiz coasts (Fig. 8a). The analysis of tsunami waves' propagation near-shore El Jadida show some similarities in the waves' behaviour with those triggered by both the HS and the MP scenarios (Fig. 8b). These similarities are due to the close location of these seismic faults as well as to the almost similar fault azimuth. Waves from the GBF (Gorringe Bank fault) reach the nearshore areas of El Jadida with maximum amplitudes of about 


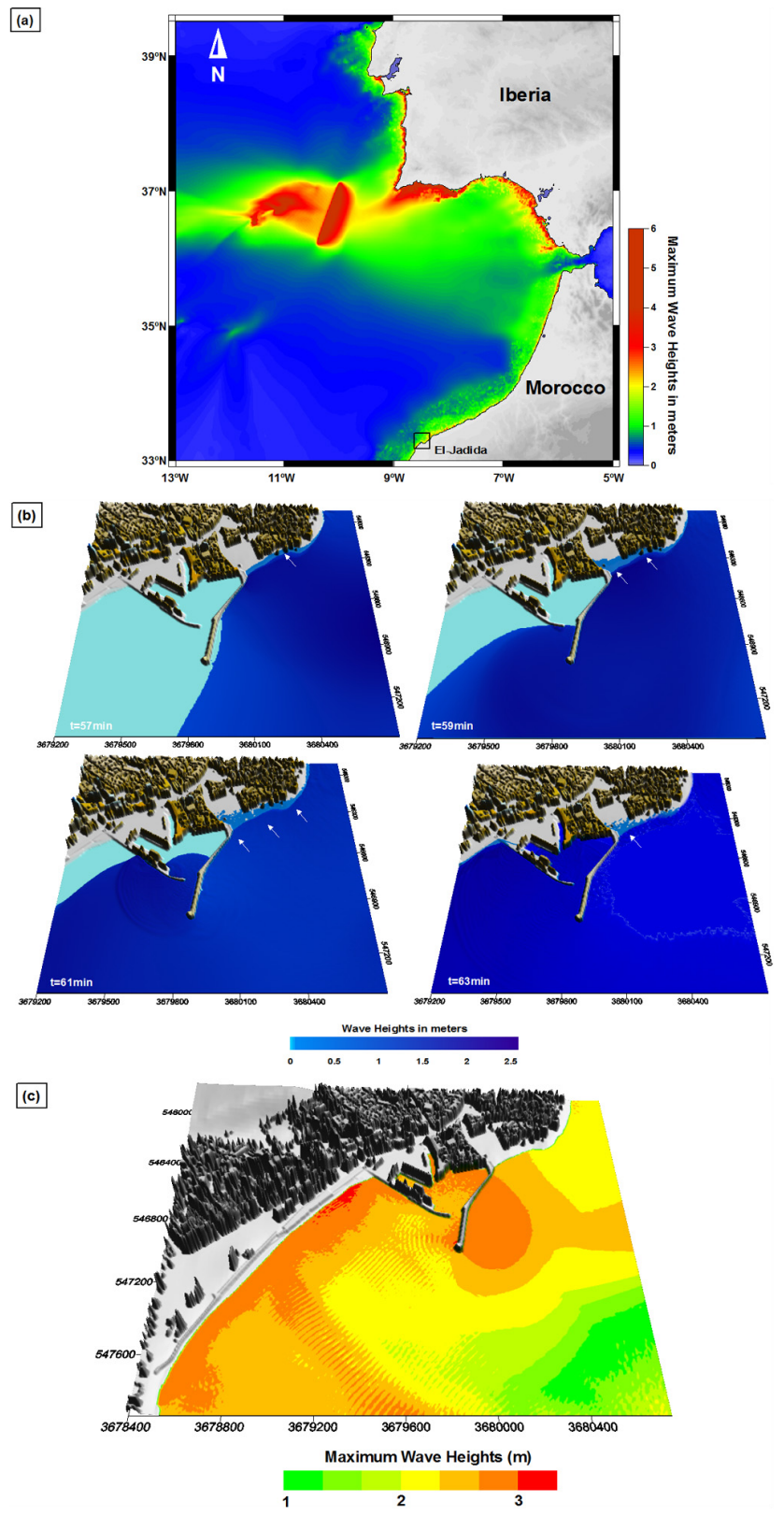

Fig. 7. Tsunami waves' propagation and near-shore behaviour for the $M_{\mathrm{W}}=8.3 \mathrm{MP}$ scenario: (a) regional tsunami energy patterns; (b) snapshots of near-shore tsunami propagation at El Jadida site; the white arrows indicate the overtopping locations; (c) maximum wave heights distribution near coasts and the harbour of the studied area.

$5.5 \mathrm{~m}$ (Fig. 8c). These wave height values are considered small regarding the relatively large magnitude of the scenario. The Gorringe Bank feature plays an important role in reducing the tsunami energy propagated towards the coasts of Morocco. In spite of this, the incident waves overtop the coastal barriers at some locations (white arrows in Fig. 8b), causing the flood of significant zones of the studied site.

\subsubsection{The Cadiz Wedge $(C W)$ scenario $M_{\mathrm{w}}=8.6$}

The Cadiz Wedge subduction slab was proposed by Gutscher (2004) as being responsible for generating the 1755 event. Numerical modelling indicates that the location and azimuth of the $\mathrm{CW}$ scenario constrain the tsunami energy patterns and most energy is steered towards the Strait of Gibraltar (Fig. 9a). The tsunami caused by this scenario, compared to the other considered scenarios (i.e. HS, MP, and GB scenarios), has different characteristics and wave propagation directivity near-shore El Jadida (Fig. 9b). The waves reach the El Jadida harbour area from northeast without encountering, initially, the main harbour breakwater (Fig. 9b). This fact allows the entrance and propagation of tsunami waves in the harbour basin with no significant tsunami energy dispersion due to waves' reflections. No significant overtopping of coastal protective structures is computed. Predicted maximum wave amplitudes range from $1 \mathrm{~m}$ to about $3 \mathrm{~m}$ (Fig. 9c) surrounding the El Jadida area.

\subsection{Inland tsunami inundation and current velocity}

This paper investigates also the inland impact resulting from the tsunami scenario, causing the great impact in the studied site. The tsunami impact at El Jadida is evaluated through computing the inundation and current velocity considering the entire time of propagation ( $2 \mathrm{~h} 30 \mathrm{~min}$ ). Results of numerical computations of maximum flow depth and current velocity for the $M_{\mathrm{w}}=8.5 \mathrm{HS}$ scenario (considered as the 1755-like event that causes the worst impact at El Jadida) are illustrated in Figs. 10 and 11, respectively.

Predicted maximum flow depths reach $\sim 7 \mathrm{~m}$ at some locations of the studied site for the $M_{\mathrm{w}}=8.5$ HS scenario (Fig. 10). These maximum values especially concern the low-lying and unprotected zones. Tsunami waves succeed in advancing inland as far as hundreds of metres from the shoreline, and a maximum inundation distance of $850 \mathrm{~m}$ is computed. The beach area and its surroundings are the zones most affected by inundation. Also, results show that some coastal structures and buildings are completely flooded by the incident waves, especially those located at the city beach and close to the harbour. The large flooded areas as well as the high values of flow depths, obtained from numerical computations, indicate a high tsunami impact that the studied area could experience in the case of occurrence of a large tsunami event in the Gulf of Cadiz region.

When the tsunami approaches the shoreline and starts advancing overland, one of the components that plays a crucial role in controlling the level of impact is the waves' current velocity. Figure 11 presents current velocities offshore and onshore the coastal area of El Jadida. Predicted tsunami speeds map (Fig. 11) shows offshore velocities that range from $6 \mathrm{~m} \mathrm{~s}^{-1}$ to $14 \mathrm{~m} \mathrm{~s}^{-1}$. Inside the harbour the current velocity is as high as $9 \mathrm{~m} \mathrm{~s}^{-1}$, while it decreases to about $6 \mathrm{~m} \mathrm{~s}^{-1}$ in very shallow water areas close to the beach where 


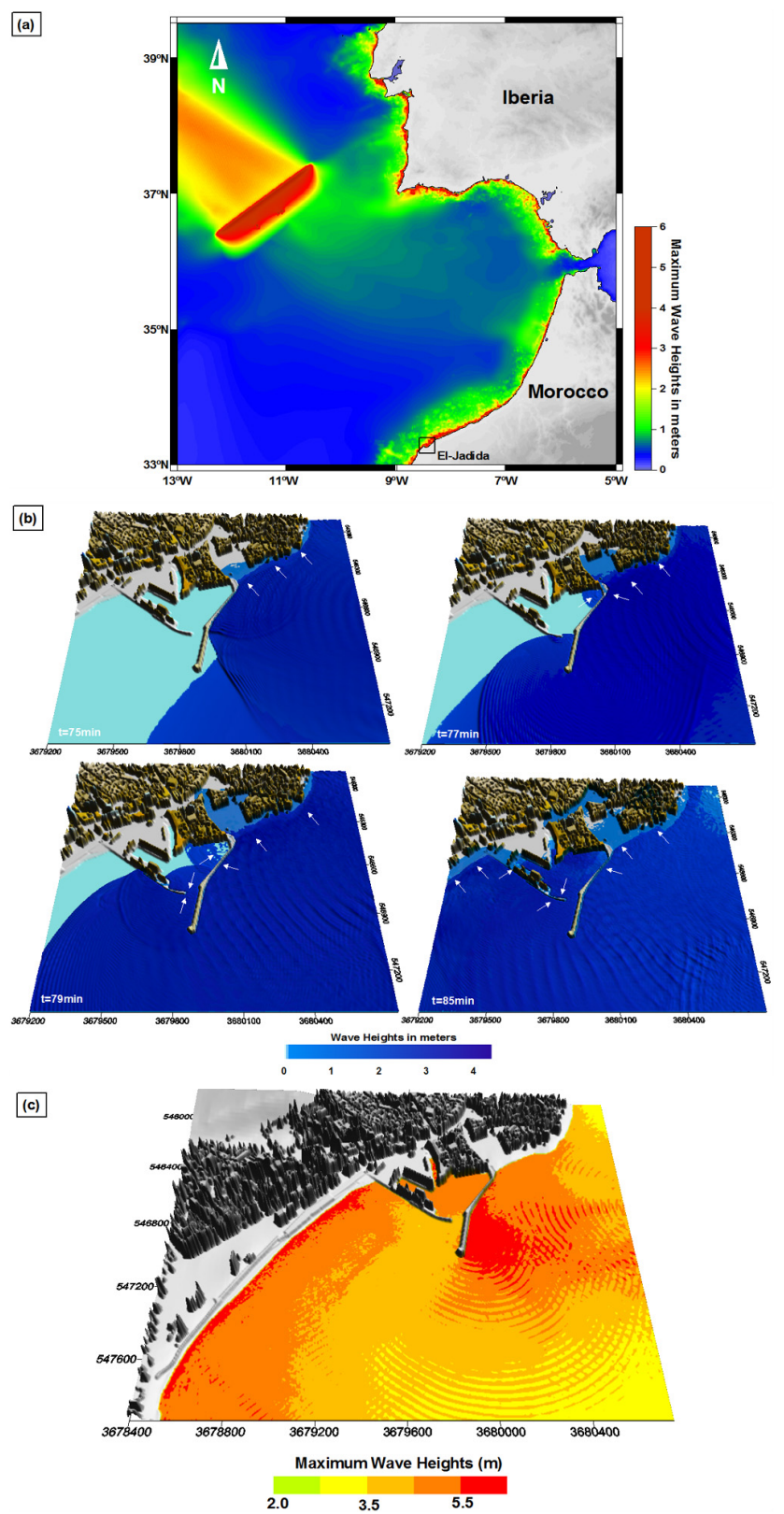

Fig. 8. Tsunami waves' propagation and near-shore behaviour for the $M_{\mathrm{W}}=8.6 \mathrm{~GB}$ scenario: (a) regional tsunami energy patterns; (b) snapshots of near-shore tsunami propagation at El Jadida site; the white arrows indicate the overtopping locations; (c) maximum wave heights distribution near coasts and the harbour of the studied area.

the bottom friction becomes increasingly important. Close to the offshore coastal barriers the current speed exceeds $10 \mathrm{~m} \mathrm{~s}^{-1}$ at some locations. The high velocities inside the harbour and close to the defense structures could have destructive impact on coastal facilities and boats. On the other hand, the overland velocities reach $8 \mathrm{~m} \mathrm{~s}^{-1}$ at some locations of the studied area. On the sandy beach, the waves' speeds are significant and range from $3 \mathrm{~ms}^{-1}$ to about $5 \mathrm{~ms}^{-1}$. (a)
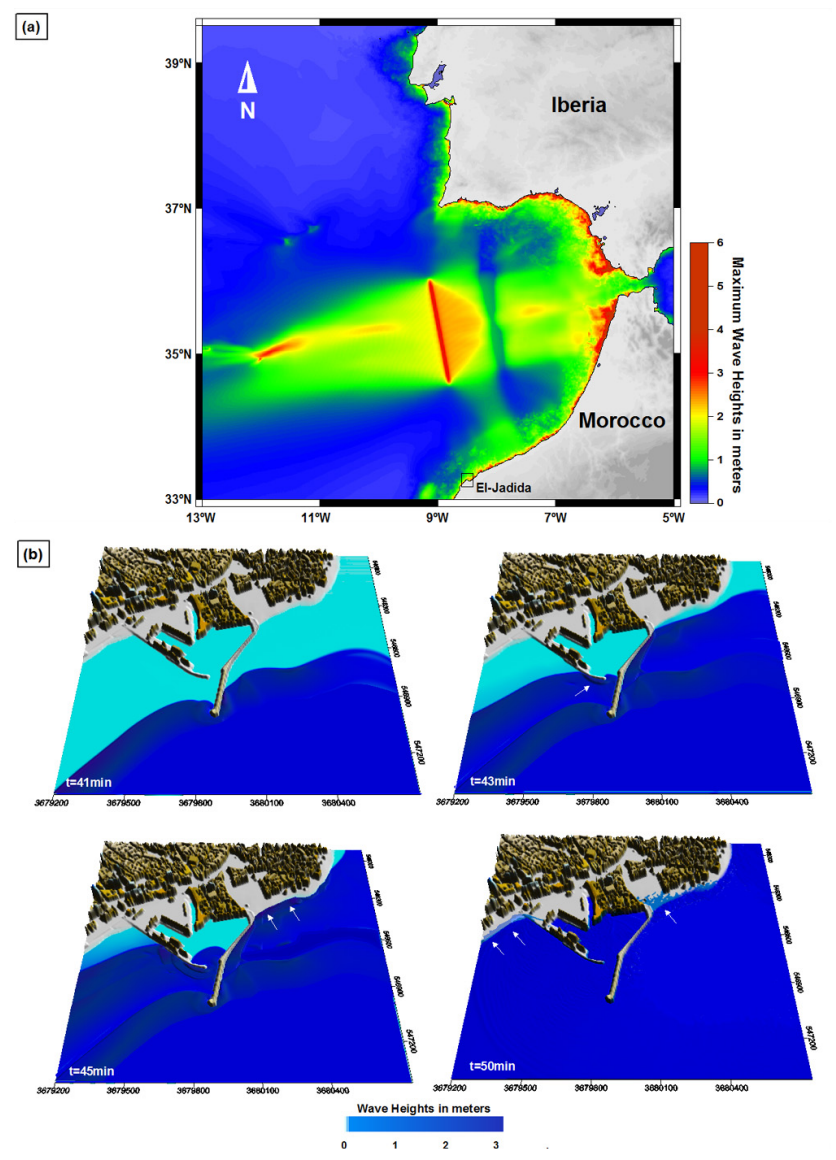

(c)

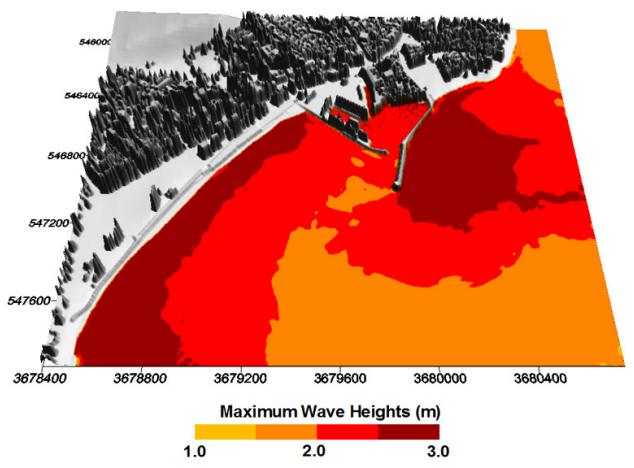

Fig. 9. Tsunami waves' propagation and near-shore behaviour for the $M_{\mathrm{W}}=8.6 \mathrm{CW}$ scenario: (a) regional tsunami energy patterns; (b) snapshots of near-shore tsunami propagation at El Jadida site; the white arrows indicate the overtopping locations; (c) maximum wave heights distribution near coasts and the harbour of the studied area.

Waves with this range of velocity could have a tremendous impact on coastal buildings, objects on the streets and coastal population. As expected, results show that significant current velocities are computed at the unprotected coastal areas where no barriers can slow down the tsunami waves. These speeds decrease behind the protective structures and at the inundation limits. 


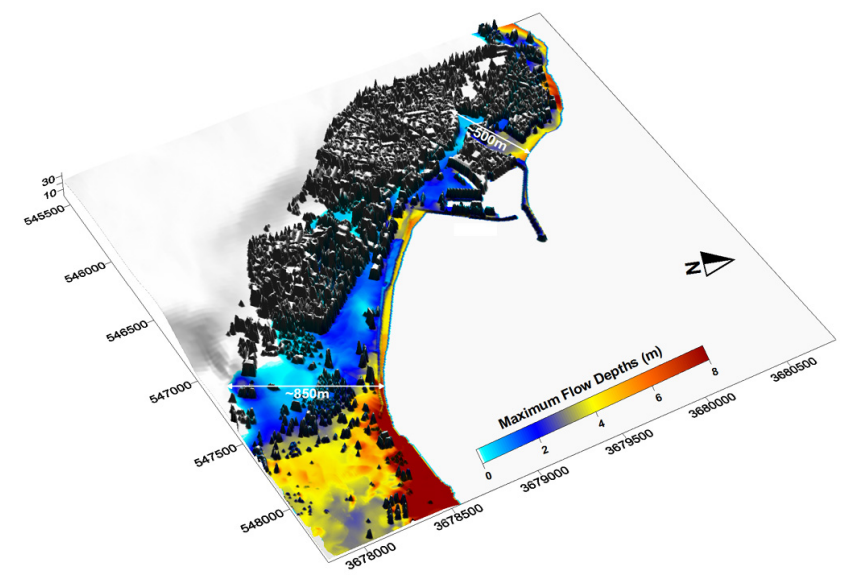

Fig. 10. Overland inundation map for El Jadida-site considering the $M_{\mathrm{W}}=8.5$ HS scenario.

\section{Discussion}

\subsection{Tsunami propagation}

It is clear that the bathymetry of the propagation domain, the fault location and its strike (azimuth) are the main factors that constrain the tsunami energy distribution and wave heights steering (Figs. 5a-9a). For the HS, MP, and GB scenarios having close locations, NW of El Jadida site, the near-shore tsunami propagations present some similarities in characteristics and directivity. When tsunami waves triggered by these scenarios approach the El Jadida coast, they are affected by the shallow bathymetry, leading to similarities in the directivity of propagation in spite of the difference observed in the tsunami energy patterns at a regional scale as well as tsunami arrival time (Figs. 5b-9b). The exception concerns the $\mathrm{CW}$ scenario, for which the tsunami propagation nearshore has different directivity from the other considered scenarios. This is mainly due to the location of this source NE of El Jadida site causing tsunami propagation and energy patterns totally different compared to the other sources even in the shallow areas of El Jadida. Among all considered scenarios, the $M_{\mathrm{w}}=8.5 \mathrm{HS}$ scenario seems the most effective in radiating the maximum tsunami energy towards the studied site, leading to the worst impact at El Jadida.

\subsection{Tsunami impact at El Jadida}

Results of numerical simulations indicate a great impact due to tsunami waves at El Jadida for the $M_{\mathrm{w}}=8.5 \mathrm{HS}$ scenario. The high tsunami impact at this coastal segment of Morocco resulted from various factors that include (i) the shoaling effect that is very important due to long extension of the shallow platform, (ii) the flat topography that allows the tsunami to advance overland and flood large areas, (iii) the poor design of the sea-barriers and the lack of coastal seadefense structures that can prevent the tsunami inundation,

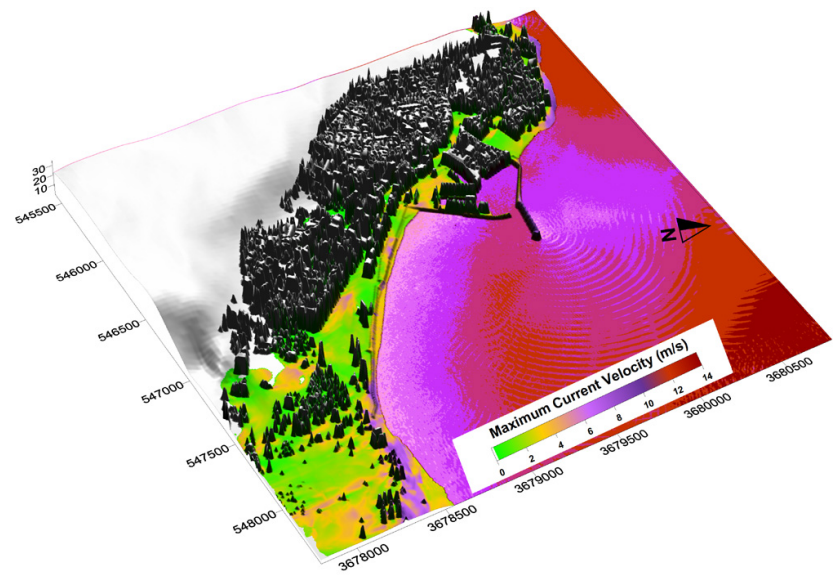

Fig. 11. Computed current velocities offshore and within the inundated area of El Jadida considering the $M_{\mathrm{W}}=8.5 \mathrm{HS}$ scenario.

and (iv) the presence of numerous streets perpendicular to the coastline which channel the tsunami flood.

Offshore structures such as breakwaters are the first structures that interact with tsunami waves. These protective structures, if they are strong enough, can withstand the impact and limit the tsunami damage and causalities. They can also reduce the tsunami energy by slowing down and/or reflecting the incident waves. At El Jadida site, results of the near-shore behaviour of tsunami waves show that the breakwaters play a crucial role in dispersing the tsunami energy of the various scenarios, namely the $M_{\mathrm{w}}=8.0$ HS (1969like event), the $M_{\mathrm{w}}=8.2 \mathrm{MP}$ scenarios and the $M_{\mathrm{w}}=8.6$ $\mathrm{CW}$. On the other hand, these structures failed to prevent the overtopping of waves generated by some 1755-like tsunami events $\left(M_{\mathrm{w}}=8.5 \mathrm{HS}\right.$ and $M_{\mathrm{w}}=8.5 \mathrm{~GB}$ scenarios $)$. This clearly indicates that sea-defenses at El Jadida site are not designed for extreme tsunami cases. Moreover, we can conclude that in the case of a 1755-like or greater event, waves can easily overtop the coastal barriers and succeed in inundating large areas. Therefore, these infrastructures, which could perform well at least for small tsunamis, should benefit from measures of maintenance and conservation because the re-design of new sea-barriers is usually very costly.

Overland flow depths, predicted in the case of a 1755-like event $\left(M_{\mathrm{w}}=8.5\right.$ HS scenario), are so high that they completely flooded several structures among the existing building stock. Most buildings along the El Jadida coast, except those of the Old Medina, are engineered reinforced concrete (RC) structures. This fact can play a positive role in limiting the damage due to the impact of tsunami waves as well as reducing the risk of total destruction and collapse. According to Yeh (2007), the buoyant forces of a tsunami concern especially buildings of small resistance to upward forces and have no significant effects on RC structures. This fact was observed for the wooden dwelling houses carried away by the Japan tsunami of 11 March 2011. On the other hand, the 


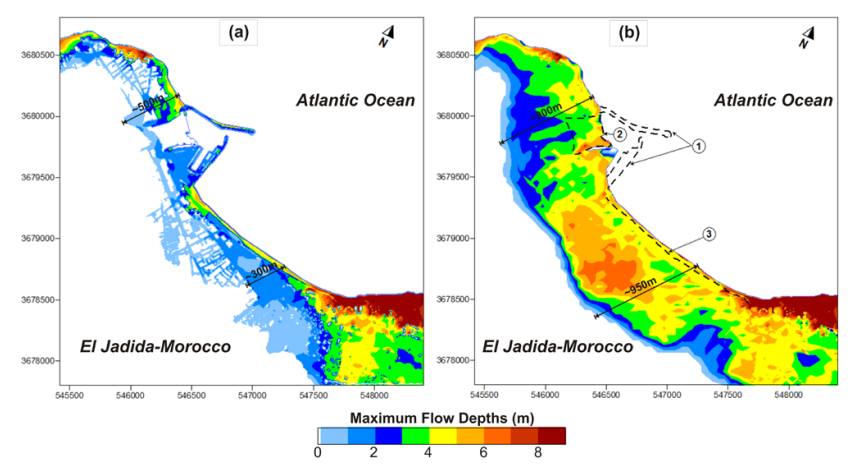

Fig. 12. Overland Impact at El Jadida due to a 1755-like tsunami event: (a) maximum flow depths distribution considering the existing coastal protective structures and buildings; (b) maximum flow depth without coastal defense structures and buildings. The dashed black lines in Fig. $8 \mathrm{~b}$ represent the protective structures that are considered in the case with coastal structures (Fig. 8a) and that are not taken into account in the case without coastal structures (Fig. 8b): (1) breakwaters, (2) Medina wall, and (3) beach sea-walls.

post-tsunami analysis of damage in Japan coastal buildings revealed that trapped air may cause substantial up-lift forces even in RC buildings (Suppasri et al., 2012). Hence, the occurrence of a 1755-like tsunami event could cause massive damages even for RC buildings at El Jadida. Moreover, the number of tsunami casualties in this highly occupied area could increase due to the absence of evacuation plans and shelters.

If we assume that the coastal barriers and structures are robust enough to resist to tsunami waves' impact, the risk of inundation could be reduced due to dissipation of tsunami energy when interacting with these structures. In Fig. 12, we present a comparison of tsunami inundation area and limits for two different cases with (Fig. 12a) and without (Fig. 12b) coastal structures of the studied site, considering the $M_{\mathrm{w}}=8.5 \mathrm{HS}$ scenario as a 1755 -like event. The case with coastal infrastructures consists of using a digital terrain model that incorporates, in addition to the coastal topography, the existing present-day coastal barriers and buildings. For the case without infrastructures, we use only the topography with no man-made structures to compute inundation parameters. A comparison between results in Fig. 12a and $b$ clearly indicates that the presence of coastal infrastructures (barriers and buildings) substantially reduces the tsunami impact in terms of flow depth, inundation area and flood distance. Close to the harbour, the maximum inundation distance is $\sim 500 \mathrm{~m}$ for the case with coastal structures (Fig. 12a), while it reaches $\sim 900 \mathrm{~m}$ for the case without coastal structures (Fig. 12b). At a location behind the sandy beach of the city, we compute a flood distance of $\sim 300 \mathrm{~m}$ if coastal structures are considered and $\sim 950 \mathrm{~m}$ if not. Also, over $3 \mathrm{~km}^{2}$ of the studied area is flooded when no coastal structures are considered and only an area of $\sim 1.8 \mathrm{~km}^{2}$ is inundated if these structures are taken into account.
In addition to flow depths, the tsunami current velocity is a crucial factor that controls the level of damage within the flooded area. During the Tohoku-oki tsunami, the high speeds generated strong tsunami currents that carried floating objects and even cars. This fact increases the debris impact forces of the tsunami that are known as a dominant cause of structures destruction (Yeh, 2007). In the study area, the average predicted overland flow speed is about $3 \mathrm{~m} \mathrm{~s}^{-1}$. Within the flooded area, the tsunami current velocity is relatively high, from $3 \mathrm{~ms}^{-1}$ to over $5 \mathrm{~ms}^{-1}$, at the sandy beach and low-lying unprotected zones (Fig. 11). Generally, people in such unprotected areas are more exposed to high tsunami waves and strong current velocities. On the other hand, results show that flow speeds become small in the zones behind protective structures and close to the limits of inundation. These areas, even though inundated, might be considered safe.

The flow speed is normally constrained by the bottom friction (Omira et al., 2011) and the presence of obstacles that can slow down the tsunami waves. Therefore, areas with high flow speeds do not always correspond to areas with high flow depths. This fact is clearly illustrated in Figs. 10 and 11 where inundation depths are maximal close to the beach while current velocities are not. This is due to the fact that the tsunami interacts first with the breakwaters (see Fig. 6) and then propagates in the shallow bathymetry, leading to slowing down the waves.

It is important to mention here that the present work suffers from two main limitations: (i) the coastal structures are considered only as obstacles and the expected tsunami damage on those sea-defenses and coastal buildings is not evaluated; and (ii) the tide near-shore El Jadida is not considered, with which wave heights could increase due to the interaction tsunami-tide, allowing for a high risk of inundation even for small or moderate tsunamis (although the possibility of simultaneous occurrence of high tide and tsunami worst-case scenario is very low). This limitation could be overcome by simulating the scenario with the proper tide. In spite of these limitations, the present paper gives insight into the performance demands that existing sea-defense structures face to tsunami overtopping as well as the tsunami impact along the Atlantic coasts of Morocco for different tsunami wave conditions.

\subsection{The need of tsunami preparedness and warning system in the region}

In the Gulf of Cadiz coastal areas, various studies have been addressed to investigate tsunami impact (Lima et al., 2010; Omira et al., 2011; Baptista et al., 2011a), and the area's vulnerability (Omira et al., 2010). These works and this paper show the high level of destruction that coastal areas of Morocco, Portugal and Spain could experience following the occurrence of large regional tsunami events, and hence the need for robust TWS in the region to mitigate the tsunami hazard. 
On the other hand, the relatively low occurrence frequency of earthquake-triggered tsunamis in the region, as the last catastrophic event happened $\sim 250 \mathrm{yr}$ ago, makes the justification of the implementation of an end-to-end TWS in the region more difficult. However, the experience of the 2004 Sumatra tsunami event highlighted the fact that infrequency does not mean total absence of threat of occurrence of devastating tsunami events (Lavigne et al., 2009). This raises the following question: should we wait for a devastating tsunami event in the region before mobilizing for the implementation of an end-to-end TWS?

The tsunami hazard in the Gulf of Cadiz region, which is an important component of a TWS, is well established through the elaboration of the historical tsunami catalogs (Baptista and Miranda, 2009; Kaabouben et al., 2009; Blanc, 2009), the definition of the tsunamigenic scenarios (Omira et al., 2009), the identification of tsunami deposits (Ruiz et al., 2005; Font et al., 2010; Medina et al., 2011; Costa et al., 2011), and the estimations of the waves' impact (Omira et al., 2010, 2011; Lima et al., 2010; Baptista et al., 2011a). Moreover, major efforts have been addressed to enhance the seismic network to cover areas around the Azores-Gibraltar plate boundary, and in particular the Cadiz Gulf region. In this region, the tsunami detection component is missing, especially its deep ocean part, as the coastal tide gauges network is relatively dense even though only a few stations are operating in real time.

Omira et al. (2009) investigated the design of a sea-level tsunami detection network in the Gulf of Cadiz region in order to provide a maximum warning time to the impacted coasts. This study promotes a particular TWS for the region that is based on a DART-like network and tide-gauge sensors. Both specificity of tsunamigenic potential and numerical modelling of tsunami triggered by most credible earthquake scenarios in the region were taken into account by Omira et al. (2009) to define the appropriate way for tsunameters deployment. For criteria of DART station locations choice, they also considered the fact that the warning time is a function of the tsunami travel time, delays in sealevel data transmission, and delays for tsunami detection and confirmation. A network of three DART-like stations, as the minimal number of offshore sensors, is proposed to detect all possible tsunamis triggered by most credible earthquake scenarios in the region as well as to provide a maximum warning time for the threatened community. For the coastal segment of El Jadida, Omira et al. (2009) showed that a warning time of 30-35 min is expected if DART offshore stations are deployed. Providing such warning time is of great importance for a tsunami evacuation process in the studied area.

On the other hand, the implementation of a robust tsunami early warning system does not mean the total safety for people in the vulnerable coastal areas, especially because the region suffers from local and regional tsunami threat. Those people must be prepared to act appropriately in case of tsunami alert. Also, public education programmes allow- ing the proper response to tsunami disaster case must be implemented. Moreover, the tsunami mitigation programme in the region should include evacuation plans, refuge areas and in-place vertical evacuation buildings.

\section{Conclusions}

Effectiveness of sea-defense structures in preventing/reducing the tsunami inundation has been investigated for El Jadida, Morocco. Various tsunami scenarios of different earthquake magnitudes, from 8.0 to 8.6 , have been considered in order to generate different tsunami wave conditions near-shore. Tsunamis triggered by the $M_{\mathrm{w}}=8.0$ HS and the $M_{\mathrm{w}}=8.2 \mathrm{MP}$ scenarios failed to overtop the existing coastal barriers that play an important role in dissipating the energy of incident waves. In the considered cases of higher scenarios magnitudes $(>=8.5)$, the generated waves caused significant overtopping of coastal structures of the studied area. The tsunami impact in terms of inundation from the $M_{\mathrm{w}}=8.5$ HS scenario is the worst among the considered scenarios. A greater earthquake, with respect to its location and azimuth, will, therefore, cause a dramatic tsunami impact and flooding in the studied area.

Construction of new sea-walls and barriers along the studied area is expensive and requires high-maintenance costs with no insurance of safety. One of the important lessons learned from the 11 March 2011 Japanese tsunami is that the construction of robust coastal barriers does not mean total safety for the endangered population. Therefore, more efforts in the studied area, as along all coasts of the Gulf of Cadiz, must be addressed to tsunami education and awareness of the coastal population. Such kind of preparedness can reduce human losses in case of occurrence of catastrophic tsunami events. Also, measures can be taken to provide coastal buildings with in-place vertical evacuation. This can support the TWS expected for implementation in the region.

The implementation of an end-to-end TWS in the northeast Atlantic region remains a priority as it is the most realistic way to provide an acceptable level of safety to the coastal population in the Gulf of Cadiz. The need for this system in the region is addressed in detail in the recent works of Omira et al. (2009) and Baptista et al. (2011b) in which a possible design of the TWS is proposed and efforts taken by countries of the region on the establishment of regional TWS are highlighted.

Acknowledgements. This work is funded by TRIDEC (Collaborative, Complex and Critical Decision-Support in Evolving Crises) FP7, EU project, and by the MAREMOTI (mareograph and field tsunami observations, modelling and vulnerability studies for northeast Atlantic and western Mediterranean) French project. Authors wish to thank REMER (Réseau National des Sciences et Techniques de la Mer) of Morocco, which supported this study through a student scholarship. Our gratitude is also addressed to the reviewers for taking time to review this paper. 
Edited by: S. Tinti

Reviewed by: Í. Aniel-Quiroga Zorrilla and R. Tonini

\section{References}

Baptista, M. A. and Miranda, J. M.: Revision of the Portuguese catalog of tsunamis, Nat. Hazards Earth Syst. Sci., 9, 25-42, doi:10.5194/nhess-9-25-2009, 2009.

Baptista, M. A., Miranda, P., and Mendes-Victor, L.: Maximum Entropy analysis of Portuguese tsunami data; the tsunamis of 28.02.1969 and 26.05.1975, Sci. Tsunami Hazards, 10, 9-20, 1992.

Baptista, M. A., Heitor, S., Miranda, J. M., Miranda, P., and Mendes-Victor, L: The 1755 Lisbon earthquake; evaluation of the tsunami parameters, J. Geodyn., 25, 143-157, 1998.

Baptista, M. A., Miranda, J. M., Omira, R., and Antunes, C.: Potential inundation of Lisbon downtown by a 1755-like tsunami, Nat. Hazards Earth Syst. Sci., 11, 3319-3326, doi:10.5194/nhess-113319-2011, 2011a.

Baptista, M. A., Omira, R., Matias, L., Miranda, J. M., Annunziato, A., Carrilho, F., and Kaabouben, F.: On the need for a tsunami warning system in the North East Atlantic area (Gulf of Cadiz), in: The Tsunami Threat - Research and Technology, edited by: Mörner, N.-A., ISBN: 978-953-307-552-5, InTech, 1328, available at: http://www.intechopen.com/books/the-tsunamithreat-research-and-technology/, $2011 \mathrm{~b}$.

Barkan, R., ten Brink, U. S., and Lin, J.: Far field tsunami simulations of the 1755 Lisbon earthquake: Implications for tsunami hazard to the U.S. East Coast and the Caribbean, Marine Geol., 264, 109-122, doi:10.1016/j.margeo.2008.10.010, 2009.

Blanc, P.-L.: Earthquakes and tsunami in November 1755 in Morocco: a different reading of contemporaneous documentary sources, Nat. Hazards Earth Syst. Sci., 9, 725-738, doi:10.5194/nhess-9-725-2009, 2009.

Broeze, J. and Van Daalen, E. F. G.: Radiation boundary conditions for the two-dimensional wave equation from a variational principle, Math. Comp., 58, 73-82, 1992.

Costa, P. J. M., Andrade, C., Freitas, M. C., Oliveira, M. A., da Silva, C. M., Omira, R., Taborda, R., Baptista, M. A., and Dawson, A. G.: Boulder deposition during major tsunami events, Earth Surf. Proc. Land., 36, 2054-2068, doi:10.1002/esp.2228, 2011.

Edward, J. K. P., Terazaki, M., and Yamaguchi, M.: The impact of tsunami in coastal areas: Coastal protection and disaster prevention measures-Experiences from Japanese coasts, Coast. Mar. Sci., 30, 414-424, 2006.

EERI: Earthquake Engineering Research Institut Special Earthquake Report - September 2011: Learning from Earthquakes: The Tohoku, Japan, Tsunami of March 11, 2011: Effects on Structures, 14 pp., available at: http://www.eqclearinghouse.org/2011-03-11-sendai/files/ 2011/03/Japan-Tohoku-report-tsunami-bldgs.pdf., 2011.

El-Mrabet, T.: Historical seismicity in Morocco, Dissertation, Letters Faculty, University of Rabat, Morocco, 1991 (in Arabic).

Font, E., Nascimento, C., Omira, R., Baptista, M. A., and Silva, P. F.: Identification of tsunami-induced deposits using numerical modelling and rock magnetism techniques: A study case of the 1755 Lisbon tsunami in Algarve, Portugal, Phys. Earth Planet. In., 182, 187-198, doi:10.1016/j.pepi.2010.10.006, 2010.
Fukao, Y.: Thrust faulting at a lithosphere plate boundary, The Portugal earthquake of 1969, Earth Planet. Sci. Lett., 18, 205-216, 1973.

GEBCO: General Bathymetric Chart of the Oceans, available at: http://www.gebco.net/ (last access: 15 March 2011), 2011.

Geist, E. L.: Local tsunami hazards in the Pacific Northwest from Cascadia subduction zone earthquake, US Geological Survey Professional Paper 1661-B, 17 pp., 2005.

Geist, E. L. and Dmowska, R.: Local tsunamis and distributed slip at the source, Pure Appl. Geophys., 154, 485-512, 1999.

Gjevik, B., Pedersen, G., Dybesland, E., Harbitz, C. B., Miranda, P. M. A., Baptista, M. A., Mendes-Victor, L., Heinrich, P., Roche, R., and Guesmia, M.: Modeling tsunamis from earthquake sources near Gorringe Bank southwest of Portugal, J. Geophys. Res., 102, 27931-27949, doi:10.1029/97JC02179, 1997.

Gràcia, E., Daňobeita, J., Vergés, J., and the PARSIFAL-team: Mapping active faults offshore Portugal $\left(36^{\circ} \mathrm{N}-38^{\circ} \mathrm{N}\right)$ : implications for seismic hazard assessment along the southwest Iberia margin, Geology, 31, 83-86, 2003.

Gutscher, M.-A., Malod, J., Rehault, J.-P., Contruci, I., Klingelhoefer, F., Mendes-Victor, L., and Spakman, W.: Evidence for active subduction beneath Gibraltar, Geology, 30, 1071-1074, 2002.

Gutscher, M.-A., Baptista, M. A., and Miranda, J. M.: The Gibraltar Arc seismogenic zone (part 2): Constraints on a shallow east dipping fault plane source for the 1755 Lisbon earthquake provided by tsunami modelling and seismic intensity, Tectonophysics, 426, 153-166, doi:10.1016/j.tecto.2006.02.025, 2006.

JMA: Japan Meteorological Agency, available at: http://www.jma. go.jp/jma/indexe.html (last access: 15 April 2011), 2011.

Johnston, A.: Seismic moment assessment of earthquakes in stable continental regions - III, New Madrid, 1811-1812, Charleston 1886 and Lisbon 1755, Geophys. J. Int., 126, 314-344, 1996.

Kaabouben, F., Baptista, M. A., Iben Brahim, A., El Mouraouah, A., and Toto, A.: On the moroccan tsunami catalogue, Nat. Hazards Earth Syst. Sci., 9, 1227-1236, doi:10.5194/nhess-9-1227-2009, 2009.

Kajiura, K.: Tsunami source, energy and the directivity of wave radiation, Bull. Earthq. Res. Inst. Tokyo Univ., 48, 835-869, 1970.

Kozak, J. T., Moreira, V. S., and Oldroyd, D. R.: Iconography of the 1755 Lisbon Earthquake, Academy of Sciences of the Czech Republic, Prague, 82 pp., 2005.

Lavigne, F., Paris, R., Grancher, D., Wassmer, P., Brunstein, D., Vautier, F., Leone, F., Flohic, F., De Coster, B., Gunawan, T., Gomez, Ch., Setiawan, A., Cahyadi, R., and Fachrizal: Reconstruction of tsunami inland propagation on December 26, 2004 in Banda Aceh, Indonesia, through field investigations, Pure Appl. Geophys., 166, 259-281, doi:10.1007/s00024-008-04318, 2009.

Leone, F., Lavigne, F., Paris, R., Denain, J. C., and Vinet, F.: A spatial analysis of the December 26th, 2004 tsunami-induced damages: Lessons learned for a better risk assessment integrating buildings vulnerability, Appl. Geography, 31, 363-375, doi:10.1016/j.apgeog.2010.07.009, 2010.

Lima, V. V., Miranda, J. M., Baptista, M. A., Catalão, J., Gonzalez, M., Otero, L., Olabarrieta, M., Álvarez-Gómez, J. A., and Carreño, E.: Impact of a 1755-like tsunami in Huelva, Spain, Nat. Hazards Earth Syst. Sci., 10, 139-148, doi:10.5194/nhess10-139-2010, 2010. 
Liu, P. L.-F., Cho, Y.-S., Brrigs, M. J., Kanoglo, U., and Synolakis, C. E.: Runup of solitary waves on a circular island, J. Fluid Mech., 302, 259-285, 1995.

Liu, P. L.-F., Woo, S.-B., and Cho, Y.-S.: Computer programmes for tsunami propagation and inundation, Technical report, Cornell University, 1998.

Martinez-Solares, J. M. and Lopez-Arroyo, A.: The great historical 1755 earthquake: Effects and damage in Spain, J. Seismol., 8, 275-294, 2004.

Matias, L. M., Cunha, T., Annunziato, A., Baptista, M. A., and Carrilho, F.: Tsunamigenic earthquakes in the Gulf of Cadiz: fault model and recurrence, Nat. Hazards Earth Syst. Sci., 13, 1-13, doi:10.5194/nhess-13-1-2013, 2013.

MacInnes, B. T., Weiss, R., Bourgeois, J., and Pinegina, T. K.: Slip distribution of the 1952 Kamchatka great earthquake based on near-field tsunami deposits and historical records, Bull. Seismol. Soc. Am., 100, 1695-1709, doi:10.1785/0120090376, 2010.

Medina, F., Mhammdi, N., Chiguer, A., Akil, M., and Jaaidi, E. B.: The Rabat and Larache boulder fields; new examples of high-energy deposits related to storms and tsunami waves in north-western Morocco, Nat. Hazards, 59, 725-747, doi:10.1007/s11069-011-9792-x, 2010.

MET: Ministere de l'Equipement et du Transport, Royaume du Maroc, Le Port d'El Jadida, available at: http://www.mtpnet.gov.ma/MET/Secteurs/Ports/Pr\%C3\%

A9sentation/El+Jadida.htm?uid\$=\$El\%20Jadida, last access: 10 April 2012.

Mori, N., Takahatshi, T., Yasuda, T., and Yanagisawa, H.: Survey of 2011 Tohoku earthquake tsunami inundation and run-up, Geophys. Res. Lett., 38, L00G14, doi:10.1029/2011GL049210, 2011.

Okada, Y.: Surface deformation due to shear and tensile faults in a half-space, Bull. Seismol. Soc. Am., 75, 1135-1154, 1985.

Omira, R., Baptista, M. A., Matias, L., Miranda, J. M., Catita, C., Carrilho, F., and Toto, E.: Design of a Sea-level Tsunami Detection Network for the Gulf of Cadiz, Nat. Hazards Earth Syst. Sci., 9, 1327-1338, doi:10.5194/nhess-9-1327-2009, 2009.

Omira, R., Baptista, M. A., Miranda, J. M., Toto, E., Catita, C., and Catalao, J.: Tsunami vulnerability assessment of CasablancaMorocco using numerical modelling and GIS tools, Nat. Hazards, 54, 75-95, doi:10.1007/s11069-009-9454-4, 2010.

Omira, R., Baptista, M. A., and Miranda, J. M.: Evaluating tsunami impact on the Gulf of Cdaiz coast (Northeast Atlantic), Pure Appl. Geophys., 168, 1033-1043, doi:10.1007/s00024-0100217-7, 2011.

Ozaki, T.: Outline of the 2011 off the Pacific coast of Tohoku Earthquake $\left(M_{\mathrm{W}} 9.0\right)$ - Tsunami warnings/advisories and observations, Earth Planet. Space, 63, 827-830, doi:10.5047/eps.2011.06.029, 2011.

Ruffman, A.: From an Ephemerides to "Observation on The Changes of The Air": Documenting The far-field parameters of the November 1, 1755 "Lisbon" Tsunami in the western Atlantic (Abstract), Atlantic Geoscience Society 32nd Colloquium and Annual Meeting, February 3-4, Greenwhich, Nova Scotia, Program with Abstracts, 63-64, Atlantic Geology, 42, p. 111, 2006.

Ruiz, F., Rodríguez-Ramírez, A., Cáceres, L. M., Vidal, J. R., Carretero, M. I., Abad, M., Olías, M., and Pozo, M.: Evidence of high-energy events in the geological record: Midholocene evolution of the southwestern Doñana National
Park (SW Spain), Palaeogeogr. Palaeoclim., 229, 212-229, doi:10.1016/j.palaeo.2005.06.023, 2005.

Russell, J.: RCC Pilotage Foundation: The Atlantic Crossing Guide, 6th Edn., Adlard Coles Nautical, A \& C Black (Publishers) Ltd, 36 Soho Square, London W1D 3QY, 2010.

Scholz, C. H.: Scaling laws for large earthquakes: consequences for physical models, B. Seismol. Soc. Am., 72, 1-14, 1982.

SDAU - El-Jadida: Schéma Directeur de l'Aménagement Urbain de la ville d'El-Jadida, available at: www.eljadida.gov.ma/, 2004.

Sugawara, D., Imamura, F., Goto, K., Matsumoto, H., and Minoura, K.: The 2011 Tohoku-oki Earthquake Tsunami: Similarities and Differences to the 869 Jogan Tsunami on the Sendai Plain, Pure Appl. Geophys., doi:10.1007/s00024-012-0460-1, 2012.

Suppasri, A., Koshimura, S., Imai, K., Mas, E., Gokon, H., Muhari, A., and Imamura, F.: Damage characteristic and field survey of the 2011 Great East Japan tsunami in the Miyagi Prefecture, Coast. Eng. J., 54, 1250005, doi:10.1142/S0578563412500052, 2012.

Synolakis, C. E., Bernard, E. N., Titov, V. V., Kânoğlu, U., and González, F. I.: Standards, criteria, and procedures for NOAA evaluation of tsunami numerical models, NOAA Tech Memo OAR PMEL-135, NTIS: PB2007-109601, NOAA/Pacific Marine Environmental Laboratory, Seattle, 55 pp., 2007.

The New York Times: Seawalls Offered Little Protection Against Tsunami's Crushing Wave, edited by: Onishi, N., 13 March 2011, available at: http://www.nytimes.com/2011/03/14/world/ asia/14seawalls.html (last access: February 2012), 2011a.

The New York Times: In Japan, Seawall Offered a False Sense of Security, edited by: Onishi, N., 31 March 2011, available at: http: //www.nytimes.com/2011/04/02/world/asia/02wall.html (last access: February 2012), 2011b.

TRANSFER: Tsunami Risk ANd Strategies For the European Region, EU project, Sixth Framework Program, contact $\mathrm{n}^{\circ} 037058$, Final activity report, available at: http://www.transferproject.eu/, last access: November 2012, 2009.

USGS: US Geological Survey, available at: http://www.usgs.gov/ (last access: March 2011), 2011.

Wang, X.: COMCOT user manual-version 1.7. School of Civil and Environmental Engineering, Cornell University Ithaca, NY 14853, USA, available at: http://ceeserver.cee.cornell. edu/pll-group/doc/COMCOT_User_Manual_v1_7.pdf, last access: January 2010, 2009.

Wijetunge, J. J.: Field measurements and numerical simulations of the 2004 tsunami impact on the east coast of Sri Lanka, Pure Appl. Geophys., 166, 593-622, doi:10.1007/s00024-009-0458$5,2009$.

Yeh, H.: Design tsunami forces for onshore structures, J. Disaster Res., 2, 531-536, 2007.

Zitellini, N., Chierici, F., Sartori, R., and Torelli, L.: The tectonic source of the 1755 Lisbon Earthquake, Ann. Geofis., 42, 49-55, 1999.

Zitellini, N., Gràcia, E., Matias, L. M., Terrinha, P., Abreu, A. M., DeAlteriis, G., Henriet, J.-P., Dañobeitia, J., Masson, D. G., Mulder, T., Ramella, R., Somoza, L., and Diez, S.: The Quest for the Africa-Eurasia plate boundary west of the Strait of Gibraltar, Earth Planet. Sci. Lett., 280, 13-50, doi:10.1016/j.epsl.2008.12.005, 2009. 